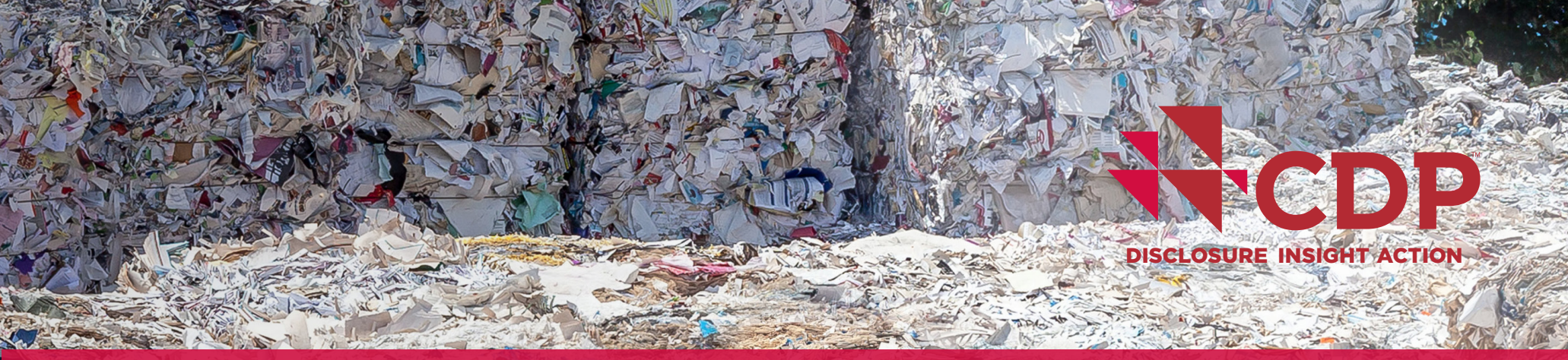

\title{
CDP Climate Change and Water Report 2020
}

Written on behalf of over 515 institutional investors with US\$106 trillion in assets |Turkey Edition

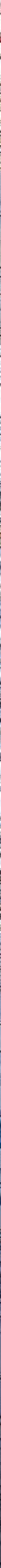




\section{CEO FOREWORD}

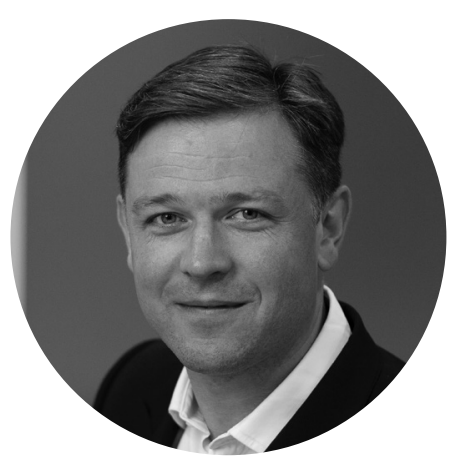

As 2021 unfolds, we reflect on the challenging and extraordinary times of the last year. As the world worked to collectively respond to the COVID-19 pandemic, we reeled from the tragic human impact of the crisis and its impact on our health, financial and social systems. Sadly, we are still grappling with these crises, but the rollout of the vaccine provides great hope for later this year.

When it comes to climate change, water security and deforestation, we have now entered a global emergency and the decade of action, our last chance to make rapid and deep cuts to global emissions and to protect biodiversity to avoid the full force of these other global crises.

When it comes to climate change, water security and deforestation, we have now entered a global emergency and the decade of action, our last chance to make rapid and deep cuts to global emissions and to protect biodiversity to avoid the full force of these other global crises.

Despite the pandemic, we are bolstered by the environmental leadership from companies, investors, governments, cities, and regions worldwide. With so much at stake and the clock running down, 2020 saw record disclosures through CDP's platform, with over 10,000 entities now disclosing their data on climate change, water security and deforestation issues. climate change hazards increasing, will lock us into a pathway of even greater risk. Instead, we must reinvent and renew our economy into one with greater resilience and more inclusivity.

Disclosure, transparency, data and science will be crucial to building a more resilient society. As we've learned from this current pandemic and from climate change, the best time for action is long before the problem becomes severe. Measuring and managing environmental risks through disclosure helps companies, cities, states and regions to build resiliency and plan for the future.

We must build back better from the COVID-19 pandemic. Our economies, societies and livelihoods depend on it.

More than 9,600 companies, worth over 50\% of global market capitalization now disclose through CDP and corporate disclosures are up $70 \%$ compared to five years ago when the Paris agreement was formed. This is in addition to the cities, states and regions that disclosed to us last year.

At CDP, we are led by the latest climate science. As it evolves, so must we, ensuring that the right information is embedded into the capital markets and placed into the hands of policymakers and decision-makers worldwide. CDP's systems enable this, and it is particularly critical as capital flows seek to transition towards the Net Zero, sustainable economy.

One thing is certain, we cannot afford to go back to 'normal' from an environmental perspective. Propping up the old system, with impending
The time for action is now.

\section{Paul Simpson}

CEO, CDP 


\section{SPONSOR FOREWORD}

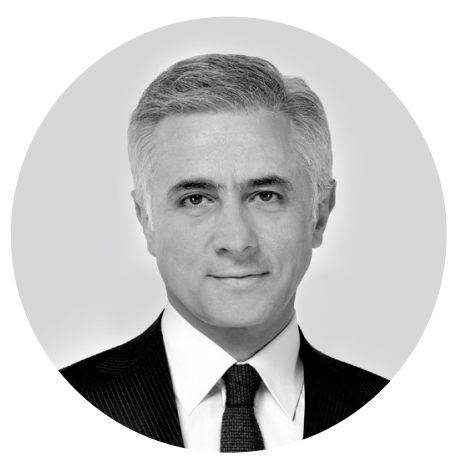

$\nabla$

Disclosing to CDP is one of the most efficient ways to communicate a powerful message to stakeholders that an organization is serious about tackling the environmental challenges material to their business. I predict that climate change is only the first of a series of sustainability or ESG issues that will come to be perceived as financial risks or, indeed, opportunities.
2020 has begun with an unprecedented shock, calling the business world's attention to the fragility and interdependence of the planet and human life. COVID-19 is the crisis of the year, addressing climate change is the crisis of the decade. It is time for a reset and action. It is the decade of ambition.

COVID-19 has caused sharp reductions in economic activity and associated fossil fuel consumption around the world in 2020. As a result, many nations are reporting significant reductions in greenhouse gas emissions for the year 2020, edging them a bit closer to meeting the initial emissions targets to which they committed under the Paris Agreement on climate change. Even though global emissions fell in 2020, they were still around the same levels as in 2012, and the drop is insignificant in comparison with the total amount of $\mathrm{CO} 2$ emitted over the past centuries. Therefore, the need for the business leadership to drive policy ambition and accelerate the transition to a zero-carbon economy is still on the front burner.

Consumers, business partners, and other entities are calling out for transparency around ESG performance with an accelerating demand day by day against those challenging times. Disclosing to CDP is one of the most efficient ways to communicate a powerful message to stakeholders that an organization is serious about tackling the environmental challenges material to their business. I predict that climate change is only the first of a series of sustainability or ESG issues that will come to be perceived as financial risks or, indeed, opportunities. 94 percent of CDP Climate Change responding companies in Turkey stated that inherent climate-related risks with the potential to have a substantive financial or strategic impact on the business this year. It is understood that the growth of sustainable finance (the integration of environmental, social, and governance criteria into investment decisions) across all asset classes will show increasing importance that investors attribute to climate change.

The 17 Sustainable Development Goals and 169 targets of the 2030 Agenda for Sustainable Development, direct world leaders for common action and endeavor across such a broad and universal policy agenda. These goals result from a process that has been more inclusive than ever, with governments involving business, civil society, and citizens from the outset we are all in agreement on where the world needs to go. Fulfilling these ambitions will take an unprecedented effort by all sectors and businesses have to play a very important role in the process.

Globally, 313 companies named on CDP's prestigious 'A List' this year for environmental transparency and action, a 45\% increase compared to 2019 is a promising indicator of green business future. I believe that by focusing on all the ways we can drive change, we can make an outsized impact on climate change. We, and other organizations who are serious about an environmentally sustainable future, need to pull all levers of influence we have. COVID-19 has proven that collective action is critical to solving urgent, global challenges. Therefore, I would like to offer my sincere thanks to all respondent companies and stakeholders who support CDP Turkey and transparent reporting development in Turkey. In rebuilding the green economy after COVID-19, I urge you to scale up your engagement with CDP and deepen your own dedication to ambition and action.

\section{Recep Baştuğ}

CEO, Garanti BBVA 


\section{PARTNER FOREWORD}

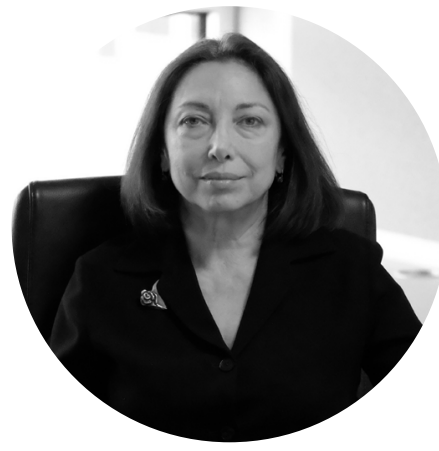

$\nabla \nabla$

This year's record level of climate and water related disclosures by Turkish companies through the CDP platform suggests that Turkey's leading companies are following the developments closely. Reporting through CDP allows gaps in measurements and disclosure to be more easily identified, by both investors and companies, and can help policy makers to develop effective policies.
In our last year's CDP report, I expressed my concerns that while the world was facing the threat of a global recession, the pandemic might shift global attention away from addressing climate change. This has not been the case. On the contrary, thanks to the changes in climate policies of the US and the enthusiastic uptake of the EU's New Green Deal by key member countries, post-pandemic economic strategies are anchored in green recovery that aim to decarbonize the economy.

A key element to foster low carbon growth and finance the transition will be to channel funding to economic activities that contribute to the objective of achieving Net Zero by 2050. Data availability is a categorical imperative to set ambitious but realistic targets and track the progress along the way. During the past months, rule makers around the world, one after the other, have announced decisions or intentions to make climate-related disclosures mandatory since scientists have urged emissions to be dropped by $50 \%$ by 2030 and reach net zero by 2050 to avoid the most catastrophic impacts of climate change.

On 3rd of March 2021, The Securities and Exchange Commission (SEC) announced that it will aggressively scrutinize the climate change disclosures of listed firms. It is expected to introduce rules forcing firms to reveal how climate change or efforts to fight it may affect their business. The task force is also poised to examine whether investment advisors' and private fund managers' environmental, social and governance related disclosures match their respective processes and practices, and their proxy voting policies and votes align with their disclosed strategies. In short, they will be forced to walk the walk.

On 8th of March this year, the IFRS (International Financial Reporting Standards) Foundation Trustees also updated their strategic direction to strengthen financial corporate reporting, by taking account of the financial opportunities and risks of sustainability impacts on enterprise value creation. On the same day, European Financial Reporting Advisory Group published a report on the development of EU Sustainability Reporting Standards.
Eliminating emissions from their portfolios is becoming a greater focus for investors as regulators push them to move from talk to action and use their influence and resources to hold companies to account. On the 29th of March the world's largest asset managers, Blackrock and Vanguard have joined The Net Zero Asset Managers initiative that consists of investors collectively managing $\$ 22.8$ trillion of assets, committing to cut the net greenhouse-gas emissions of their portfolios to zero by 2050. Most of them are also investor signatories of CDP.

All these indicate the beginning of a new disclosure and reporting era that will integrate financial and non-financial disclosure and reporting. A key departure from the previous era is that the general acceptance of 'double materiality', meaning that businesses should report on financially material topics that not only influence enterprise value but also on topics material to the economy, environment, and people. With the objective of making climate change disclosure more comparable the so-called "big five" international standard setters: CDP, CDSB, GRI, IIRC and SASB, have committed to making their frameworks and standards interoperable, and developing a joint vision of how these elements could complement financial reporting based on the recommendations of Task Force on ClimateRelated Financial Disclosures (TCFD) set up by Financial Stability Board.

This year, 9600 of world's largest companies have disclosed climate-related information through CDP. This number includes more than $60 \%$ of S\&P 500 companies, representing more than $50 \%$ of the world's market cap. This year's record level of climate and water related disclosures by Turkish companies through the CDP platform suggests that Turkey's leading companies are following the developments closely. Reporting through CDP allows gaps in measurements and disclosure to be more easily identified, by both investors and companies, and can help policy makers to develop effective policies. Turkey's CDP Climate Change and Water leaders that have shown state of the art performance over the past eleven years are a source of great inspiration for the late comers and for companies in their supply chain.

Melsa Ararat, PhD

Director \& Principal Researcher, Sabancı University Corporate Governance Forum 


\section{CONTENTS}

6 RESPONDING COMPANY LIST / CLIMATE CHANGE / TURKEY 2020

7 RESPONDING COMPANY LIST / WATER SECURITY / TURKEY 2020

8 SNAPSHOT / CLIMATE CHANGE / TURKEY 2020

9 SNAPSHOT / WATER SECURITY / TURKEY 2020

10 KEY FINDINGS / CLIMATE CHANGE / TURKEY 2020

11 KEY FINDINGS / WATER SECURITY / TURKEY 2020

12 COMPANY RESPONSE SUMMARY / CLIMATE CHANGE / TURKEY 2020

14 INTRODUCTION / CLIMATE CHANGE / TURKEY 2020

16 COMPANY RESPONSES OVERVIEW / CLIMATE CHANGE / TURKEY 2020

26 A GLIMPSE INTO THE LAST 10 YEARS / CLIMATE CHANGE / TURKEY 2020

28 COMPANY RESPONSE SUMMARY / WATER SECURITY / TURKEY 2020

30 COMPANY RESPONSES OVERVIEW / WATER SECURITY / TURKEY 2020

40 SCORE DISTRIBUTION / TURKEY 2020

41 CDP TURKEY LEADERS 2020 / TURKEY 2020

42 CDP'S OTHER CAMPAIGNS AND PROGRAMS / TURKEY 2020

44 RESPONSE STATUS / CLIMATE CHANGE / TURKEY 2020

47 RESPONSE STATUS / WATER SECURITY / TURKEY 2020

49 CDP PARTNER IN TURKEY 


\section{RESPONDING COMPANY LIST CLIMATE CHANGE / TURKEY 2020}

\section{Official Investor Sample}

AFYON ÇIMENTO SANAYI T.A.Ş.

AKBANK T.A.Ş.

AKSA AKRILIK KIMYA SANAYIi A.Ş.

ALBARAKA TÜRK KATILIM BANKASI A.Ş.

ANADOLU CAM SANAYII A.Ş.

ANADOLU EFES BIRACILIK VE MALT SANAYII A.Ş.

ARÇELIK A.Ş.

ASELSAN ELEKTRONIK SANAYI VE TICARET A.Ş.

COCA-COLA IÇECEK A.Ş.

ENERJISA ENERJI A.Ş.

ENKA İNŞAAT VE SANAYI A.Ş.

FORD OTOMOTIV SANAYI A.Ş.

GENTAŞ GENEL METAL SANAYI VE TICARET A.Ş.

KARDEMIR KARABÜK DEMIR ÇELIK SANAYI VE TICARET A.Ş.

KORDSA TEKNIK TEKSTIL A.Ş.

MAVI GIYIM SANAYI VE TICARET A.Ş.

MigROS TICARET A.Ş.

NETAŞ TELEKOMÜNIKASYON A.Ş.

PEGASUS HAVA TAŞIMACILIĞI A.Ş.

POLISAN HOLDING A.Ş.

SABANCI HOLDING A.Ş.

SODA SANAYI A.Ş.

ŞEKERBANK T.A.Ş.

T.GARANTI BANKASI A.Ş.

T.iş BANKASI A.Ş.

T.SINAI KALKINMA BANKASI A.Ş.

T.ŞiŞE VE CAM FABRIKALARI A.Ş.

TEKFEN HOLDING A.Ş.

TOFAŞ TÜRK OTOMOBIL FABRIKASI A.Ş.

TRAKYA CAM SANAYII A.Ş.

TURKCELL İETIŞiM HiZMETLERi A.Ş.

TÜRK TELEKOMÜNIKASYON A.Ş.

TÜRKIYE HALK BANKASI A.Ş.

TÜRKIYE VAKIFLAR BANKASI T.A.O.

ÜLKER BISKÜVI SANAYI A.Ş.

VESTEL ELEKTRONIK SANAYI VE TICARET A.Ş.

YAPI VE KREDI BANKASI A.Ş.

ZORLU ENERJI ELEKTRIK ÜRETIM A.Ş.

\section{Other Responding Companies}

ABDi IBRAHIM ILAÇ SANAYI VE TICARET A.Ş.

AKÇANSA ÇIMENTO SANAYI VE TICARET A.Ş.

AKENERJI ELEKTRIK ÜRETIM A.Ş.

AYDEM YENILENEBILIR ENERJI A.Ş.

BRISA BRIDGESTONE SABANCI LASTIK SAN. VE TiC. A.Ş.

CARREFOURSA CARREFOUR SABANCI TICARET MERKEZI A.Ş.

ÇIMSA ÇIMENTO SANAYI VE TICARET A.Ş.

DURAN DOĞAN BASIM VE AMBALAJ A.Ş.

EKOTEN SANAYI VE TEKSTIL A.Ş.

ETI SODA A.Ş.

GAZDAŞ GAZIANTEP DOĞAL DAĞITIM A.Ş.

GENEL ENERGY PLC

IHLAS EV ALETLERI IMALAT SANAYI VE TICARET A.Ş.

KAYSERI ULAŞIM A.Ş.

OSMANGAZI ELEKTRIK DAĞITIM A.Ş.

PINAR ENTEGRE ET VE UN SANAYIi A.Ş.

PINAR SÜT MAMULLERI SANAYIi A.Ş.

SUN TEKSTIL SANAYI VE TICARET A.Ş.

TÜRKIYE KALKINMA VE YATIRIM BANKASI A.Ş.

VESTEL BEYAZ EŞYA SANAYI VE TICARET A.Ş.

YÜNSA YÜNLÜ SANAYI VE TICARET A.Ş.

ZORLU DOĞAL ELEKTRIK ÜRETIMI A.Ş. 


\section{RESPONDING COMPANY LIST \\ WATER SECURITY / TURKEY 2020}

\section{Official Investor Sample}

AFYON ÇIMENTO SANAYI T.A.Ş.

AKÇANSA ÇIMENTO SANAYI VE TICARET A.Ş.

AKENERJi ELEKTRIK ÜRETIM A.Ş.

AKSA AKRILIK KIMYA SANAYIi A.Ş.

ARÇELIK A.Ş.

BRISA BRIDGESTONE SABANCI LASTIK SAN. VE TIC. A.Ş.

CARREFOURSA CARREFOUR SABANCI TICARET MERKEZI A.Ş.

COCA-COLA IÇECEK A.Ş.

ÇIMSA ÇIMENTO SANAYI VE TICARET A.Ş.

ENERJISA ENERJI A.Ş.

ENKA INŞAAT VE SANAYI A.Ş.

FORD OTOMOTIV SANAYI A.Ş.

KORDSA TEKNIK TEKSTIL A.Ş.

MIGROS TICARET A.Ş.

POLISAN HOLDING A.Ş.

TEKFEN HOLDING A.Ş.

TOFAŞ TÜRK OTOMOBIL FABRIKASI A.Ş.

ÜLKER BISKÜVI SANAYI A.Ş.

VESTEL BEYAZ EŞYA SANAYI VE TICARET A.Ş.

VESTEL ELEKTRONIK SANAYI VE TICARET A.Ş.

ZORLU ENERJi ELEKTRIK ÜRETIM A.Ş.

\section{Other Responding Companies}

ABDi IBRAHIM ILAÇ SANAYI VE TICARET A.Ş.

ALBARAKA TÜRK KATILIM BANKASI A.Ş.

AYDEM YENILENEBILIR ENERJi A.Ş.

DURAN DOĞAN BASIM VE AMBALAJ A.Ş.

ETI SODA A.Ş.

IHLAS EV ALETLERI IMALAT SANAYI VE TICARET A.Ş.

PINAR ENTEGRE ET VE UN SANAYIi A.Ş.

PINAR SÜT MAMULLERI SANAYIi A.Ş.

SABANCI HOLDING A.Ş.

ŞEKERBANK T.A.Ş.

T.GARANTI BANKASI A.Ş.

TÜRKIYE HALK BANKASI A.Ş.

YAPI VE KREDI BANKASI A.Ş.

YÜNSA YÜNLÜ SANAYI VE TICARET A.Ş.

ZORLU DOĞAL ELEKTRIK ÜRETIMI A.Ş. 


\section{SNAPSHOT \\ CLIMATE CHANGE / TURKEY 2020}

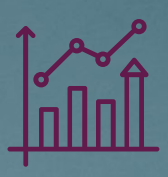

Response Summary \& Current State

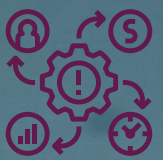

Climate Change Management
$60 \mid \begin{aligned} & \text { Total number of } \\ & \text { responding companies }\end{aligned}$

38 Number of responding BIST-100

36 Number of A and B

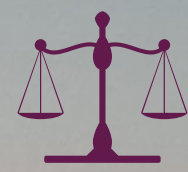

Risks

\section{$89 \%$}

Reporting engagement with the value chain on climate-related issues
$16 \%$ Organization has carbon transition plan to support the long- term business strategy

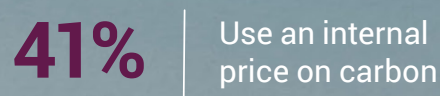

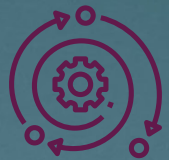

\section{Governance \& Strategy}

Board-level oversight of climate-related issues within the organization

Provide monatary incentives for the management of climate-related issues

Use climate-related scenario analysis to inform organization's business strategy
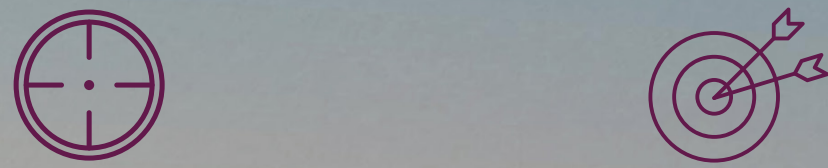

\section{Targets} \& Performance

Carbon pricing mechanisms are one of the risk drivers that have a financial or strategic impact
Have an emissions target that was active in the reporting year

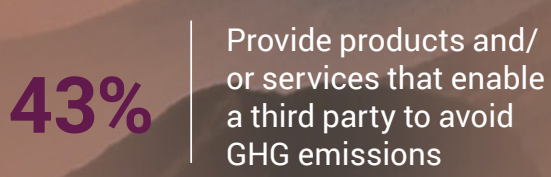

Have no Science Based Target yet but anticipate setting one in the next 2 years
$59 \%$
Potential financial impact of the risks billion identified

\section{0}

Total number of

opportunities

identified as relevant

Shift in consumer preferences is one of the risk drivers that have a financial or strategic impact

12.8

billion

Dollars
Potential

financial

impact of the opportunities identified 


\section{SNAPSHOT \\ WATER SECURITY / TURKEY 2020}

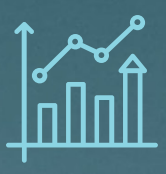

Response Summary \& Current State

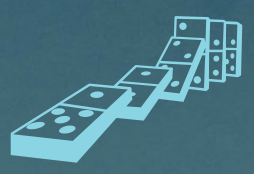

Business Impacts \& Procedures

Governance \& Strategy

\begin{tabular}{l|l} 
Undertook a water- \\
related risk assessment
\end{tabular}

910

Regulators are the most considered stakeholders in organization's water-

related risk assessments measured and monitored

Engage with the value chain on water-related issues

\section{$26 \% \mid \begin{aligned} & \text { Organization has } \\ & \text { experienced detrimental } \\ & \text { water-related impacts }\end{aligned}$ \\ $26 \% \mid \begin{aligned} & \text { Organization has } \\ & \text { experienced detrimental } \\ & \text { water-related impacts }\end{aligned}$ \\ $26 \% \mid \begin{aligned} & \text { Organization has } \\ & \text { experienced detrimental } \\ & \text { water-related impacts }\end{aligned}$}

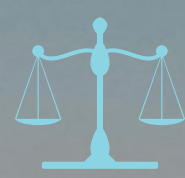

Risks

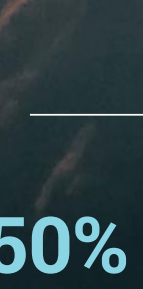

$47 \%$

Anticipate risks to materialize within 1 - 6 years

Flooding is the primary risk driver in direct operations that have a substantive financial or strategic impact

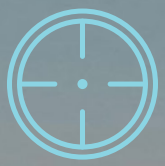

\section{Targets} \& Performance

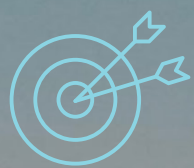

Reported board-level oversight of waterrelated issues within the organization \begin{tabular}{l|l}
$79 \%$ & $\begin{array}{l}\text { Respondents that have a } \\
\text { water policy }\end{array}$
\end{tabular}

Water-related issues are integrated into financial planning of the organization

\section{Opportunities}

More than half of company-wide facilities are exposed to water risks

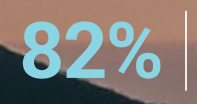

Company-wide targets and goals are in place
Respondents that provide quantitative metric for water targets

\section{Efficiency is one of the opportunities that could have a substantive financial or strategic impact \\ 10 Anticipate opportunities to materialize within 1 - 6 years \\ $71 \%$}

Reduced environmental $50 \%$ impacts reported as the most common primary motivation behind water targets

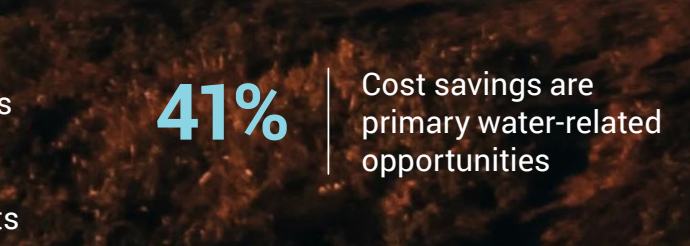




\section{CLIMATE CHANGE / TURKEY 2020}

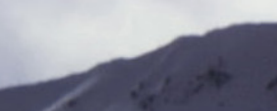

Within Turkey operation, the number of companies responding to CDP's Climate Change Program has reached 60 in 2020 that represents a significant increase from 2019, even amidst the Covid- 19 crisis. This confirms the CDP's view that environmental reporting should continue despite the pandemic.

Management and leadership levels (A \& B scores) require demonstration of good or leading environmental performance as well as transparency. In 2020, the number of $A$ and $B$ band scored companies in Turkey is 36 in total. That number is steadily increasing year by year. In Turkey, Garanti BBVA made the Global CDP Climate A list and Tekfen Holding achieved a 'double $A$ ' score for Global Climate and Water, being one of the 63 companies in the World. 8 companies (5 in 2019) achieved a score of 'A-' across Climate Change are recognized as pioneers of business in Turkey for environmental reporting.

CDP's annual Supplier Engagement Rating (SER) provides a rating for how effectively companies are engaging their suppliers on climate change since 2018 . By engaging their suppliers on climate change, companies are playing a crucial role in the transition towards the net-zero sustainable economy. We have 3 companies in Turkey achieved a score of A: Arçelik, Brisa and Garanti BBVA. A further 11 companies from various sectors also receive 'A-'.

C-suite positions are identified as being particularly pertinent as they escalate environmental issues from being kept in a CSR/ESG department toward broader integration in organization-wide practices. While almost all companies $(98 \%)$ disclose that they have board-level oversight on climate-related issues, not enough is held by critical C-suite directors (56\%).

Within responding companies, offering incentives to senior leadership to ensure environmental goals are achieved is more of an established practice with climate change (93\%), while it remains nascent for water security (59\%).

Responding companies in Turkey have started to act, but to be aligned with the scientific consensus that provides the basis of the Paris Agreement, efforts will need to ramp up significantly. While it was encouraging to find key environmental metrics are broadly being disclosed, companies are needed to have the right targets in place to decrease their impact. The number of companies implementing forwardlooking mechanisms to plan for the low-carbon transition is still low in Turkey:

\footnotetext{
- Science-based targets (SBTs) further demonstrate corporate leadership and ensure resiliency, climate change preparedness and the ability and intention to stay ahead of ever-changing regulatory and business environments. A very small number of companies in Turkey setting targets aligned with science ( $9 \%$ ) and only $33 \%$ anticipate setting one in the next two years.
}

- Since the practice of setting emissions reduction targets has become standard business practice and is an expectation from capital market stakeholders, the proportion of companies setting targets to reduce their GHG emissions is $80 \%$ in Turkey. However, renewable energy consumption (19\%) or production ( $9 \%$ ) targets remains extremely low.

- $41 \%$ of companies report the use of an internal carbon price, compared to $27 \%$ last year allowing them to be ready for future costs imposed by either emissions trading schemes or carbon taxes, with a further one fifth expecting to do so within the next two years. This growth is largely driven by the parallel development of regulations that directly or indirectly price carbon and the increasing pressure from shareholders and customers. More than a quarter $(28 \%)$ of responding companies see the use of an internal carbon pricing system as a way to change internal behavior in the company. A further $19 \%$ use it to drive energy efficiency and $17 \%$ to drive low carbon investment.

- Although all companies (100\%) in Turkey stated that they have integrated climate change into their business strategy, the amount of companies conducting climate change scenario analysis to understand strategic implications of climate-related risks and opportunities (72\%) suggests that there is still a room for improvement.

$46 \%$ of responding companies in Turkey have developed a low-carbon transition plan to support the long-term business strategy to respond to climate-related risks and capitalize on opportunities. This remarkable increase from last year (16\% in 2019) proves that companies in Turkey are stepping up to respond to climate-related risks and find opportunities in the transition towards a sustainable, low-carbon economy.

Risk assessment is a vital process that helps companies understand their vulnerabilities and drive appropriate action where it's needed most. While most companies identify inherent climate-related risks with the potential to have a substantive financial or strategic impact on the business (94\%), many others (67\%) provided at least one figure for the potential financial impact of the risk.

The most commonly reported risk type with the potential to have a substantive financial or strategic impact on the business is related to emerging regulation (65\%). This is attributable to the recent national and international developments on carbon markets, carbon tax and climate law. Acute (59\%) and chronic (46\%) physical risks are following which is attributable to the recent temperature changes and extreme weather conditions, which affect almost all sectors in Turkey. By far the most commonly reported risk driver with the potential to have a substantive financial or strategic impact on the business is carbon pricing mechanisms (59\%) in 2020. Given the growth of carbon pricing regulation globally, this is unsurprising. 
COVID-19 has demonstrated that future climate shocks present a threat. Companies must go beyond disclosure to monitor and fully engage their value chains to address critical physical climate and environmental risks. However, value chain engagement is relatively shallow for the responding companies. While $89 \%$ of companies engage in some way with their value chain on climate change, just $30 \%$ provide details of organization's climate-related supplier engagement strategy with more than half of their suppliers.

While there are promising signs of companies identifying and capitalizing on opportunities ( $89 \%)$, there is a critical shortage of reported opportunities aimed at increasing resilience in the face of a changing environment ( $9 \%)$.

$87 \%$ of companies in Turkey report active emissions reduction initiatives in the reporting year. More than half of companies (54\%) reported that the initiatives are related to energy efficiency in production processes. Unsurprisingly, energy efficiency in buildings (48\%) comes after with a huge potential to save carbon emissions. Half of the reporting companies $(50 \%)$ believe that their active emission reduction initiatives will payback in less than a year.

\section{KEY FINDINGS WATER SECURITY / TURKEY 2020}

More companies (13\% increase compared to previous year) than ever are disclosing on water issues and seeing the benefits of their disclosure. Triple the number of companies are showing leadership on water issues (9 in 2020, 3 in 2019). Tekfen Holding achieved a 'double A' score for Global Climate and Water Programs.

Responding to risks and seizing opportunities requires awareness, monitoring, transparency and disclosure. However, many companies in Turkey seem to be unaware of their exposure to water risks. Although $91 \%$ undertake a waterrelated risk assessment, only $26 \%$ reported that they have experienced any detrimental water-related impacts.

V The economic imperative to turn the world's water crisis around is stronger than ever. The combined financial risk reported in 2020 topped out at US\$733 million in Turkey. This figure may be an underestimate, however, as $44 \%$ of respondents failed to provide financial values of the risks they face.

Most companies try to reduce their water consumption through recycling and reusing. But despite these efforts the demand for water in industrial activities is still not decreasing as it is needed. While $29 \%$ of responding companies have measured that, their water consumption is lower than the previous year, $32 \%$ report an increase. In terms of water withdrawals, $44 \%$ of responding companies report a decrease, while $29 \%$ measured an increase compared to previous year.
The most common explanation that companies provide for increased withdrawals is an increase in production.

53 percent of responding companies reported that more than half of total withdrawals sourced from water stressed areas which is much higher compare to the previous year $(39 \%)$. Most of the water withdrawal is sourced from third party sources $(71 \%)$ and most of the water is discharged to third party destinations (76\%) which shows water crosses the company boundary, at either the corporate level or facility level.

Water related regulatory frameworks is the most considered contextual issues in the company's waterrelated risk assessments. Assessment at the basin level poses challenges for companies, given that it requires an understanding of the activities and needs of local communities and other local water users. $71 \%$ of companies in Turkey conduct risk assessment with a consideration of river basin management authorities and a further $88 \%$ with local communities. Regulators are the most considered stakeholders (91\%) that are considered in the company's water-related risk assessments.

Water-exposed companies should conduct risk assessments that are company-wide and comprehensive, including their direct operations and their supply chains. However, only $35 \%$ of disclosing companies meet this higher standard.

Physical risks are the most reported types of risks in the direct operations (77\%) and in the value chain (38\%). In direct operations, physical risks were reported mostly as a result of increased operating costs (29\%) and reduction or disruption in production capacity (15\%). Increased operating costs are also the most reported potential impact (38\%) of identified risks in the direct operations; in the value chain, the most reported risk drivers are drought (15\%) and increased water scarcity $(9 \%)$.

While $82 \%$ companies have some type of water-related target or goal in place, $56 \%$ of them stated that more than half of targets are achieved. Reduced environmental impacts $(50 \%)$ is the primary motivation behind targets and the primary motivation behind the goals is water stewardship (32\%).

The COVID-19 pandemic has revealed how fragile and complex supply chains can be and companies that assess risk and engage their value chains are finding strategic value in doing so. However, value chain engagement is relatively shallow for the responding companies in Turkey. While $76 \%$ of companies engage in some way with their value chain on water, just $24 \%$ request from more than half of suppliers to report on their water use, risks and/or management information.

Looking at the longer term $85 \%$ of respondents in Turkey are integrating water-related issues into organization's longterm strategic business plan. A further $44 \%$ integrated those issues into strategic business plan for more than 10 years. While $74 \%$ of companies have considered water-related issues in their financial planning, $82 \%$ have considered it in their longterm business objectives. 


\section{COMPANY RESPONSE SUMMARY} CLIMATE CHANGE / TURKEY 2020

\section{CARBON PRICING}

Carbon pricing has emerged as a key policy mechanism to drive greenhouse gas emissions reductions and mitigate the dangerous impacts of climate change. As the number of jurisdictions with carbon pricing policies has doubled over the last decade, this module examines details on the operations or activities regulated by carbon pricing systems, carbon credits, and internal prices on carbon.

$\mathbf{4 1 \%}$ use an internal price on carbon

\section{GOVERNANCE}

This module aims to capture the governance structure of the company with regard to climate change and provides data users with an understanding of the organization's approach to climate-related issues at the board and below board-level. The results demonstrate that the responding companies in Turkey have strong governance structures and strategies for climate change.

v $\mathbf{9 8} \%$ have board-level oversight of climate-related issues within the organization

\ $\mathbf{9 3} \%$ provide incentives for the management of climate-related issues

\ $\mathbf{9 2} \%$ have climate risk management procedures in place

\section{EMISSIONS}

A meaningful and consistent comparison of emissions over time is an essential step in understanding and reducing negative environmental impacts. This module allows companies to provide a base year and base year emissions and provide details of the standard, protocol, or methodology used to collect activity data and calculate Scope 1 and Scope 2 emissions.

- $93 \%$ reported Scope 1 \& 2 emissions

$\checkmark \mathbf{6 5 \%}$ reported a decrease in Scope 1 \& 2 emissions

$\mathbf{2 5}$ \% reported an increase in Scope 1 \& 2 emissions

\section{ENGAGEMENT}

In order to reach a net-zero future, companies must engage with their value chain on climate-related issues. This module examine how organizations are working with their suppliers, customers and other stakeholders and provide data users with insight into the different types of activities in which organizations engage to influence public policy on climate-related issues.

$\mathbf{8 9}$ reported engagement with the value chain in climate-related issues

v $\mathbf{5 2} \%$ published voluntary sustainability report

$\mathbf{3 0} \%$ reported engagement with more than $50 \%$ of suppliers

$\mathbf{3 0} \%$ reported engagement with more than $50 \%$ of suppliers

(n)




\section{ENERGY}

Energy-related activities represent the most significant GHG emission sources. Accurate accounting of emissions depends on a comprehensive account of energy. This module provides transparency on the consumption and generation of energy by organizations.

- $\mathbf{4 6 \%}$ have energy consumption totals from renewable sources (excluding feedstocks) in MWh. $>0$

\section{VERIFICATION}

Verification and assurance are good practices in environmental reporting as they ensure the quality of data and processes disclosed. This module requests details on the verification status that applies to organizations' reported Scope 1, 2 and 3 emissions, as well as on the verification of other climate-related information reported in the CDP disclosure.

Third-party verification or assurance process in place;

$$
\begin{aligned}
& \text { \ Scope } 1 \& 2 \quad \mathbf{7 0} \% \\
& \text { \ Scope } 3 \quad \mathbf{4 1 \%}
\end{aligned}
$$

\section{RISKS}

This module helps companies to evaluate exposure to climaterelated risks and opportunities over a range of time horizons, which is crucial to set a strategy for the low-carbon transition recognized in the Paris Agreement and UN SDGs. Responding companies appear particularly mindful of the reputational and regulatory risks posed by climate change.

V $\mathbf{9 4 \%}$ identified any inherent climate-related risks with the potential to have a substantive financial or strategic impact on the business.

Most commonly reported risk types with the potential to have a substantive financial or strategic impact on the business:

$\begin{array}{lll}\nabla & \text { Emerging regulation } & \mathbf{6 5 \%} \\ \nabla & \mathbf{5 9 \%} \\ \nabla & \text { Chronic physical } & \mathbf{4 6 \%} \\ \nabla & \mathbf{3 7 \%} \\ \mathbf{\nabla} \text { Market } & \mathbf{3 3 \%}\end{array}$

\section{OPPORTUNITIES}

Besides the challenges that companies face, climate change also presents opportunities. Among the companies that responded to the opportunities module in 2020 , products \& services, and resource efficiency are the most reported opportunity types considered in the organization's climate-related risk assessments.

$\mathbf{8 9} \%$ identified any inherent climate-related opportunities with the potential to have a substantive financial or strategic impact on the business.

Most commonly reported opportunity types with the potential to have a substantive financial or strategic impact on your business:

$\begin{array}{lll}\text { Products and services } & \mathbf{7 2 \%} \\ & \text { Resource efficiency } & \mathbf{4 4 \%} \\ & \text { Energy source } & \mathbf{3 5 \%} \\ & \text { Markets } & \mathbf{3 1 \%} \\ & \text { Resilience } & \mathbf{9 \%}\end{array}$

\section{STRATEGY}

CDP data users are interested in companies' forward-looking strategies and financial decisions that are driven by climate-related future market opportunities, public policy objectives, and corporate responsibilities. This module allows organizations to disclose whether they integrate climate-related issues into their business strategy, have a transition planning, or use scenario analysis to inform business strategy. 


\section{$\checkmark$ Net-zero transformation after Covid-19 crisis}

Within Turkey operation, the number of companies responding to CDP's Climate Change Program has reached 60 in 2020 and 36 companies responded to the CDP's Water Security Program that represents a significant increase from 2019, even amidst the Covid-19 crisis. In fact, this confirms the CDP's view that environmental reporting should continue despite the pandemic. Obviously, The Covid-19 crisis has fundamentally changed the world. This global crisis has illustrated how vulnerable the global economy is but the emergence of this threat does not reduce the need to respond to the ongoing climate emergency, which remains the most significant long-term threat to economic and social stability.

We believe that sustainability goals remain important, and as CDP, we will continue to support companies and cities in our mutual goal of addressing the global challenges of climate change, deforestation and water security. The current global health crisis shows resiliency in supply chains and business models is more essential than ever. Companies with a core sustainability focus are better positioned to withstand the impacts of systemic shocks, including the inevitable impacts of climate change.

We also believe that we need to pay attention the economic recovery steps that will follow the Covid-19 crisis and we should urge investors, governments, and policy makers to comply with the Paris Agreement goals. Our recovery efforts should lead us to a more sustainable economic system because this is the only way to be resilient to future shocks. Policy makers, businesses, and society leaders should work collectively for the post-covid economic recovery with ambitious climate actions.
In that regard, we believe the guidance of science is more important than ever. Global carbon emissions need to reach net-zero by 2050 at the latest, to limit global warming to $1.5^{\circ} \mathrm{C}$ as indicated in the Paris Agreement. Setting GHG emissions reduction targets in line with climate science is necessary to meet the goals of the Paris Agreement and to limit global warming. For that reason, CDP is supporting companies to set their targets based on science as one of the founding partners of the Science-Based Targets Initiative (SBTi). We have 18 companies in Turkey committed to set a sciencebased target in two years' time as of 2023. Two of them already submitted their target and get approval from SBTi. Since climate change presents material risks to investments and companies, investors also urge companies to set Science-Based Targets, so they can decarbonize their portfolios and mitigate climate-related risks to which they may be exposed. CDP is asking for corporate data on behalf of hundreds of investors and we can observe that the tide is rapidly turning against companies not taking note of investor demands.

CDP has launched the biggest ever NonDisclosure Campaign in 2020 with more than 100 global investors despite the pandemic. With this campaign, investors can actively target companies that have received the CDP disclosure request but have not provided a response. The objective of the campaign is to drive further corporate transparency around climate change. Many companies from Turkey received those investor letters. In the near future, these companies are likely to be exposed to further pressure from investors and even they are at risk of being excluded from investor portfolios. They need to act now.

To find a better and faster solution to recover from the Covid-19 crisis, CDP is also working with the We Mean Business
Coalition. In 2020, the coalition sent a letter to $\mathrm{G} 20$ Finance Ministers and Central Bank Governors, and hundreds of major global companies called on governments to invest in climate action and resilience by tackling climate and Covid-19 together. They believe clear and consistent government policies that drive the full decarbonisation of the economic system are critical to accelerate progress towards the zero-carbon economies of the future.

The European Commission published 'The European Green Deal' which aims to make the European economy sustainable by turning environmental problems such as climate change into advantages. It is actually a new growth strategy and obviously, Turkey is going to be affected by this policy, especially by the carbon border adjustment mechanism. The EU is set to make 'greening the economy' an essential part of its efforts to recover from the impacts of the Covid-19 crisis. These policies will set an example to the policy makers, companies and even for cities in Turkey.

It is all about just and inclusive economic recovery with ambitious climate action and our ultimate goal should be establishing zero-carbon economies. Implementing a net-zero transformation will be challenging for businesses after the Covid-19 crisis but they will be well placed to respond to the demands from the various stakeholders including investors and consumers. 


\section{What should be next steps of companies in Turkey to achieve net-zero carbon target especially after the}

Covid-19 crisis?

- Commit to net-zero: It is a milestone in transitioning your business operations and to be accountable to all of your stakeholders to deliver required change.

- Assess your climate risks: Undertaking climate scenario analysis allows you to understand the full range of possible risks and implement management methods that are specific to each scenario.

- Set ambitious 'Science-based Targets': So you will be able to map out a route to achieving them which will help your company to look at different investment and innovation opportunities and assess the impacts of meeting the targets you've set.

- Decarbonize your operations: By investing and switching to a sustainable green energy source, you will reduce your carbon footprint, meet carbon reduction targets and also cut your operational costs.

- Keep reporting your environmental impacts: Measuring and managing environmental risks through disclosure helps your company to build resiliency and plan for the future.

- Collaborate, engage and communicate: Achieving net zero requires a collaborative effort through your value chain and within your own business. 


\section{COMPANY RESPONSE OVERVIEW}

\section{0 \\ disclosing companies in total}

\section{$98 \%$}

have board-level

oversight of climaterelated issues

The Corporate Governance Committee that directly reports to the Board of Directors shapes Akbank's solution strategies for the climate change. Chairman of Akbank is also a member of Corporate Governance Committee. Investor Relations and Sustainability Department ensures coordination and management of the issue within the Bank. Other departments and sustainability team are responsible for collecting data and applying the decisions taken by the Corporate Governance Committee.
CDP is acting on behalf of $\mathbf{5 1 5}$ investors with US\$106 trillion in assets and through CDP's global platform, approximately 9600 companies voluntarily disclose their environmental information including GHG emissions, climate change strategies, climate risks and low-carbon opportunities in 2020 .

CDP requested the largest 100 companies from Borsa Istanbul 100 Index (BIST-100) and companies with high environmental impact in Turkey to disclose their environmental information in 2020. In total, 60 companies responded to CDP Climate Change Program in Turkey up from 54 ( $11 \%$ increase) in 2019. Out of 60 companies, 38 are from the official sample (BIST-100) and 22 are outside of the official sample including companies reporting voluntarily as self-selected companies (SSCs) or companies that are listed in CDP's global environmental samples. The following analysis in this report includes 54 companies in total, excluding the companies responded as See Another (SA) which means that the company is a subsidiary of a parent company which responds to CDP.

\section{Vhowing leadership on climate change: Governance \& Business Strategy}

Governance and business strategy in climate-related issues are crucial for business growth in a carbonconstrained future. Transitioning to a low-carbon economy means better climate management. To deliver real change, companies need a strategic response to the climate crisis. The response must be led from the boardroom and driven throughout the organization.

Aydem Yenilenebilir Enerji has a performance management system clearly defines the KPIs for each employee and department where promotions and bonuses are decided through the related evaluations. These KPIs also cover sustainability issues including climate-related issues. In addition, they have an employee engagement practice called New Idea Hotline project to identify innovative and proactive solutions towards climate change. Each selected project for implementation is rewarded by the company.
Responding companies in Turkey have strong governance structures and strategies for climate change. This is reflected in percentages associated with questions on senior-level responsibility associated with climate change, integration of climate change into business strategy, and having a climate risk management procedure in place. Almost all respondents (98\%) stated that they have board-level oversight of climaterelated issues within the organization; more than half $(56 \%)$ of the companies have CEO oversight.
Top management teams have integrated climate-related concerns in performance evaluation of key personnel. $93 \%$ of responding companies provide incentives for the management of climate-related issues, including the attainment of targets. A further $89 \%$ have monetary incentives.

87 percent of companies stated that climate-related risks and opportunities influenced their organization's strategy and/or financial planning. The list below shows where those risks and opportunities have influenced the financial planning of companies:

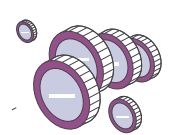

76\% Direct costs

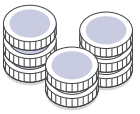

$54 \%$ Assets

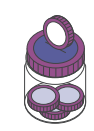

65\% Revenues

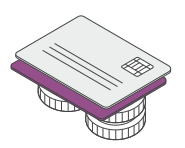

$52 \%$ Indirect costs

\section{$87 \%$}

have stated that climaterelated risks and opportunities influenced their organization's strategy and/or financial planning

\section{$72 \%$}

deploying climate-related scenario analysis for business strategy 


\section{Internal Carbon Price Examples}

\section{OFFSET}

Ford Otosan will apply an internal price on carbon before the establishment of the national carbon pricing mechanism. Ford Otosan considers voluntary market average price as part of an internal goal to offset the Scope 2 emissions. It will source approximately $864,000 \mathrm{GJ}$ of energy - annual electricity consumption at its plants - from internationally certified renewable energy sources.

\section{SHADOW PRICE}

Garanti BBVA applies its own shadow carbon price in evaluating the economics of all greenfield/brownfield fossil fuel based and renewable energy investments in its project finance activities. If the host country already implements an ETS/tax, then Garanti BBVA uses actual price for carbon. If not, it uses fixed price per tCO2e emitted. The price is determined taking into consideration the market dynamics and is reviewed and updated regularly.

\section{$46 \%$}

\section{have developed a low-}

\section{carbon transition plan to support the long-term business strategy}

Turkcell faces a group of interrelated challenges in transitioning itself to the low carbon economy while managing risks and opportunities. The strategy for the transition is based on four main aspects: Mitigation, Adaptation, New Business Models, Climate Centered Corporate Engagement and Stakeholder Participation. Turkcell aims at developing resilience by applying certain measures defined within four main areas as defined above.
Given the importance of forward-looking assessments of climate-related risks and opportunities, scenario analysis is an important and useful tool for an organization to use, both for understanding strategic implications of climate-related risks and opportunities, and for informing stakeholders of how the organization is positioning itself in recognition of these issues. It is a tool to enhance critical strategic thinking by challenging 'businessas-usual' assumptions, and to explore alternatives based on their relative impact and likelihood of occurrence. In Turkey, $72 \%$ of responding companies report that they are implementing current best practices by using a scenario-based approach to inform their corporate strategy around climate change that represents a significant increase from the previous year $(57 \%$ in 2019). $35 \%$ of companies use qualitative scenario analysis and $24 \%$ use both qualitative and quantitative approaches. A further $22 \%$ anticipate that they will introduce this over the next two years.

The transition towards a sustainable, low carbon economy will require an action across every part of the economy. Transition plans define how the business model, growth strategy and capital investments need to develop over time to respond to climate-related risks and capitalize on opportunities. $46 \%$ of responding companies in Turkey have developed a low-carbon transition plan to support the long-term business strategy. This remarkable increase from last year (16\% in 2019) proves that companies in Turkey are stepping up to respond to climate-related risks and find opportunities in the transition towards a sustainable, low-carbon economy.

The Task Force on Climate-related Financial Disclosures (TCFD) lists Internal Carbon Price (ICP) as a key metric to assess climate-related risks and opportunities in line with its strategy and risk management process. ICP has emerged as a powerful approach to assess and manage carbon-related risks and opportunities that may arise from the transition to a low-carbon economy. For many companies, the most significant consequences of these risks will emerge over time, and their magnitude is uncertain. Assigning a monetary value to the cost of carbon emissions helps companies monitor and adapt their strategies and financial planning to realtime and potential future shifts in the external market.

In $2020,41 \%$ of companies report already using an internal carbon pricing system, allowing them to be ready for future costs imposed by either emissions trading schemes or carbon taxes, with a further $20 \%$ expecting to do so within the next two years. In 2019, those figures were $27 \%$ and $33 \%$, respectively. This growth is largely driven by the parallel development of regulations that directly or indirectly price carbon and the increasing pressure from shareholders and customers for companies to adequately manage their climate-related risks.

More companies in Turkey are gradually adopting ICP and taking advantage of low-carbon investment opportunities while managing carbon risks. More than a quarter $(28 \%)$ of responding companies see the use of an internal carbon pricing system as a way to change internal behaviour in the company. A further 19\% use it to drive energy efficiency and $17 \%$ to drive low carbon investment.

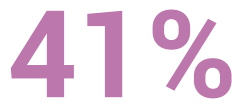

\section{use an internal carbon price}

Scenario analysis were made for Turkey and other countries ENKA is active for short, medium and long-term strategies. Scenario outcomes have been integrated in risk detection committee procedures, submitted to executive committee and integrated to individual risk assessments for projects. Diversification of business lines, new opportunities and potential investment areas have been identified. Together with other inputs and practical experience, scenario analysis has enabled company strategy to focus on low carbon business opportunities. ENKA has seen the trend and need for reducing energy related emissions and have started to update strategy considering the demand from market and clients. 


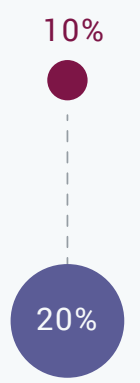

2015

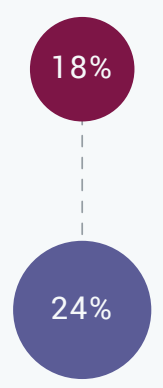

2016

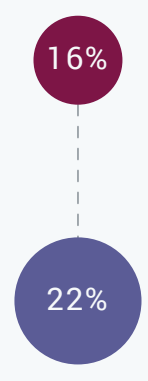

2017

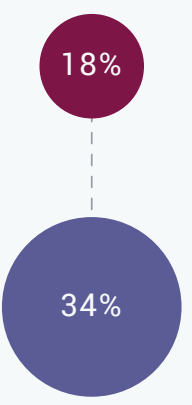

2018

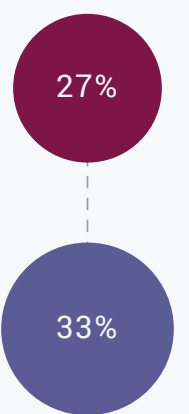

2019

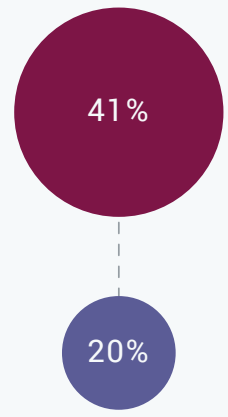

2020

Not yet (within 2 years)

Yes

\section{US\$37.3 billion}

the amount of potential financial impact of risks

\section{billion}

US\$12.8

the amount of potential financial impact of opportunities

Akenerji closely monitors regulatory changes and seeks ways for adaption before any new regulations get into force. Akenerji is evaluating emission reduction possibilities for long term plans. The strategy may involve in (1) implementing higher efficiency gas turbines, (2) phasing out low efficiency/old natural gas power plant, (3) carbon sequestration and storage and/or (4) investing in renewable energy. (5) carbon offsets by Akenerji's renewable power generation.

\section{Building resilience: Risk Assessment \& Opportunities}

Companies should be able to evaluate their exposure to climate-related risks and opportunities in order to be successful in transition to a low-carbon economy. The potential negative impacts of climate change outweigh the costs of mitigating them. There are also significant opportunities to be realized in the process of transition. Environmental stewardship of companies is directly related to the quality of the process of identifying, assessing and managing its climate-related risks and opportunities.

In Turkey, $94 \%$ of responding companies identified inherent climate-related risks with the potential to have a substantive financial or strategic impact on the business. The potential financial impact of risks identified by companies in Turkey amounts to US\$37.3 billion in total and the cost of measures taken by companies to manage those risks amounts to US\$1 billion. Total number of risks identified as relevant by responding companies is 385 .

Responding companies recognize opportunities as well as risks posed by climate change. $89 \%$ of responding companies identified potential opportunities that could have a substantive or strategic impact on their business. This number was much lower last year (78\%). However, the proportion of companies that have identified opportunities $(89 \%)$ resulting from climate change is lower than the share of companies that have identified risks ( $94 \%)$. The potential financial impact of opportunities identified by companies in Turkey amounts to US\$12.8 billion in total. Total number of opportunities identified as relevant is 180 .

The most commonly reported risk type with the potential to have a substantive financial or strategic impact on the business is related to emerging regulation (65\%).

This is attributable to the recent national and international developments on carbon markets, carbon tax and climate law. Acute (59\%) and chronic (46\%) physical risks are following which is attributable to the recent temperature changes and extreme weather conditions, which affect almost all sectors in Turkey.

Like previous year, the majority of opportunity types with the potential to have a substantive financial or strategic impact on the business are linked to products and services ( $72 \%$ ) affecting both the customer and the direct operations of the supply chain. Resource efficiencies (44\%) and alternative energy sources (35\%) are the next most frequently identified money savers.

By far the most commonly reported risk driver with the potential to have a substantive financial or strategic impact on the business is carbon pricing mechanisms (59\%) in 2020. Given the growth of carbon pricing regulation globally, this is unsurprising. The shift in consumer preferences (46\%) and development and/or expansion of low emission goods \& services (31\%) are the most commonly reported climate-related opportunity drivers.

180

total number of opportunities identified

385

total number of risks identified 
Most commonly reported risk \& opportunity drivers with the potential to have a substantive financial or strategic impact on the business

\section{! Risks drivers}

59\% Carbon pricing mechanisms

$31 \%$ Changes in precipitation patterns and

$1 \%$ extreme variability in weather patterns

$28 \%$ Rising mean temperatures

$26 \%$ changing customer behavior

\begin{tabular}{ll} 
22\% & $\begin{array}{l}\text { Mandates on and regulation of } \\
\text { existing products and services }\end{array}$ \\
\hline $\mathbf{1 9} \%$ & $\begin{array}{l}\text { Increased stakeholder concern or } \\
\text { negative stakeholder feedback }\end{array}$ \\
\hline
\end{tabular}

46\% Shift in consumer preferences

$31 \%$ Development and/or expansion of low

$22 \%$ Development of new products or services

$22 \%$ through R\&D and innovation

$20 \%$ Access to new markets

Q Use of more efficient production and

$19 \%$ distribution processes

$15 \%$ Use of lower-emission sources of energy

Most commonly reported risk \& opportunity types with the potential to have a substantive financial or strategic impact on the business

\section{! Risk types}

\begin{tabular}{|c|c|c|c|c|}
\hline $65 \%$ & $59 \%$ & $46 \%$ & $37 \%$ & $33 \%$ \\
\hline $\begin{array}{l}\text { Emerging } \\
\text { requlation }\end{array}$ & N. Acute physical & గిక్ & Markets & Reputation \\
\hline
\end{tabular}

\section{$t_{+}$Opportunity types}

$72 \%$

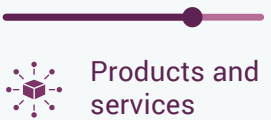

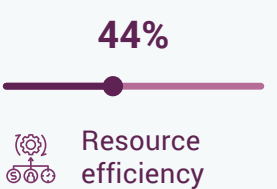

बबे० efficiency

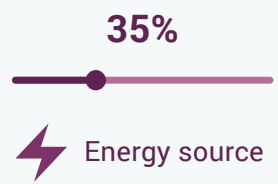

$9 \%$

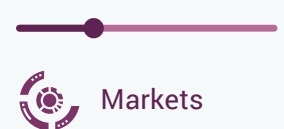

Primary potential financial impacts of the risks \& opportunities identified

! Financial impacts of the risks

$69 \%$ Increased indirect (operating) costs

44\% Increased direct costs

Decreased revenues due to reduced

$\mathbf{3 9 \%}$ Decreased revenues due to reduce

31\% Reduced revenue from decreased

$31 \%$ production capacity

$30 \%$ Increased capital expenditures

$\mathbf{1 7 \%}$ Increased credit risk

$13 \%$ Decreased access to capital
Financial impacts of the opportunities $63 \%$ increased revenues resulting from

44\% Reduced indirect (operating) costs

Increased revenues through access to $28 \%$ Increased revenues through

$26 \%$ Reduced direct costs

Increased revenues resulting from
increased production capacity




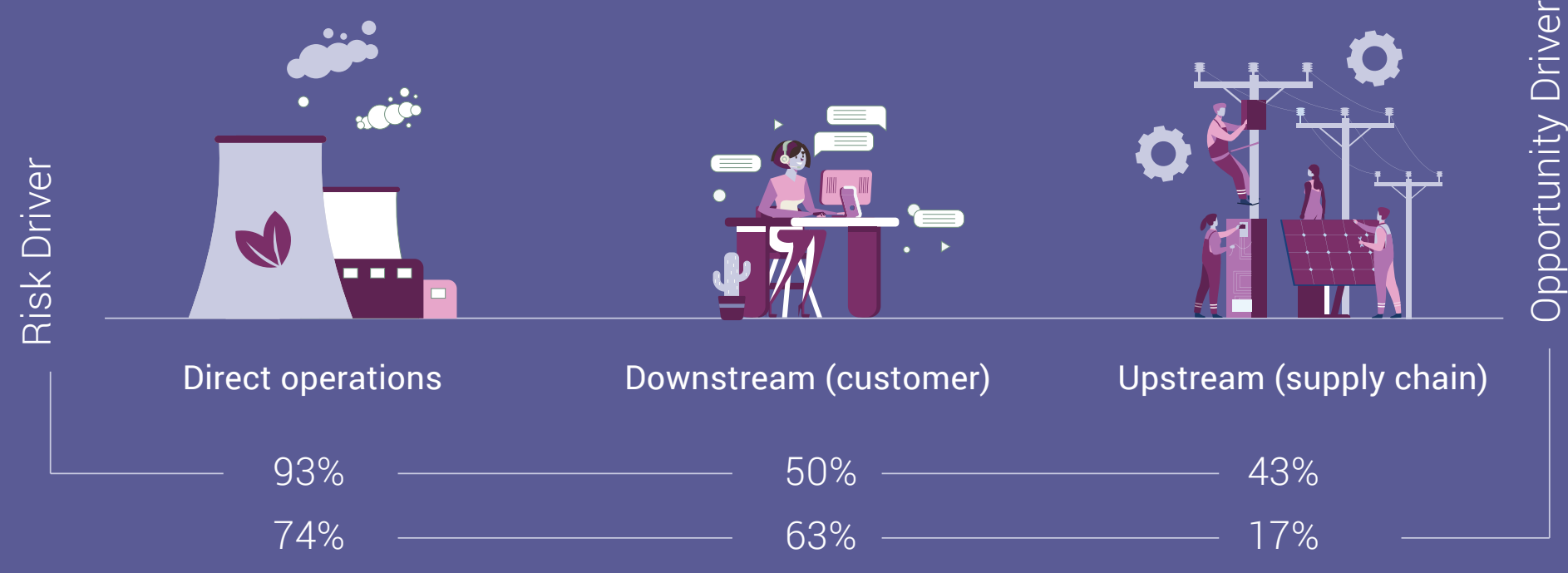

\section{Tekfen's renewable energy department}

is seeking opportunities in the oil and gas sector to diversify services to prevent the probable turnover loss likely to be caused

by the downsizing of oil and gas projects. The cost of management related to this activity includes the employment of new specialist personnel, memberships, business development activities, and outsourced services for proposal (USD 412,500). Moreover, Tekfen Construction is now getting more oil and gas

infrastructure improvement projects to enhance the performance of existing oil and gas refineries, contributing to directly optimizing their $\mathrm{GHG}$ emissions. The cost of management is approximately US\$375 thousand annually
In 2020, companies were also asked to report the primary potential financial impact figures of the risks and opportunities they disclosed as a key data point in CDP's scoring methodology. $67 \%$ of companies provided at least one figure for the potential financial impact of risks and $65 \%$ for the potential financial impact of opportunities. The top identified cause of the primary potential financial impacts of the risks is increased indirect/operating costs (69\%) that are often linked to $\mathrm{GHG}$ emissions pricing. Besides, increased revenues resulting from increased demand for products and services (63\%) are the top identified potential financial impacts of the opportunities.

The frequency and time horizon for risk assessment is also key to business resilience into a business.
CDP asked companies to define the time horizons over which they see risks and opportunities. In the direct operations, identified risks occur mostly in medium term (85\%) and opportunities in short term $(67 \%)$ future. In the value chain, the risk driver and opportunity driver occurs mostly in direct operations ( $93 \%$ and $74 \%$ accordingly).

\section{$67 \%$}

provided at least one figure for the potential financial impact of risks

Time horizon of the identified risks and opportunities

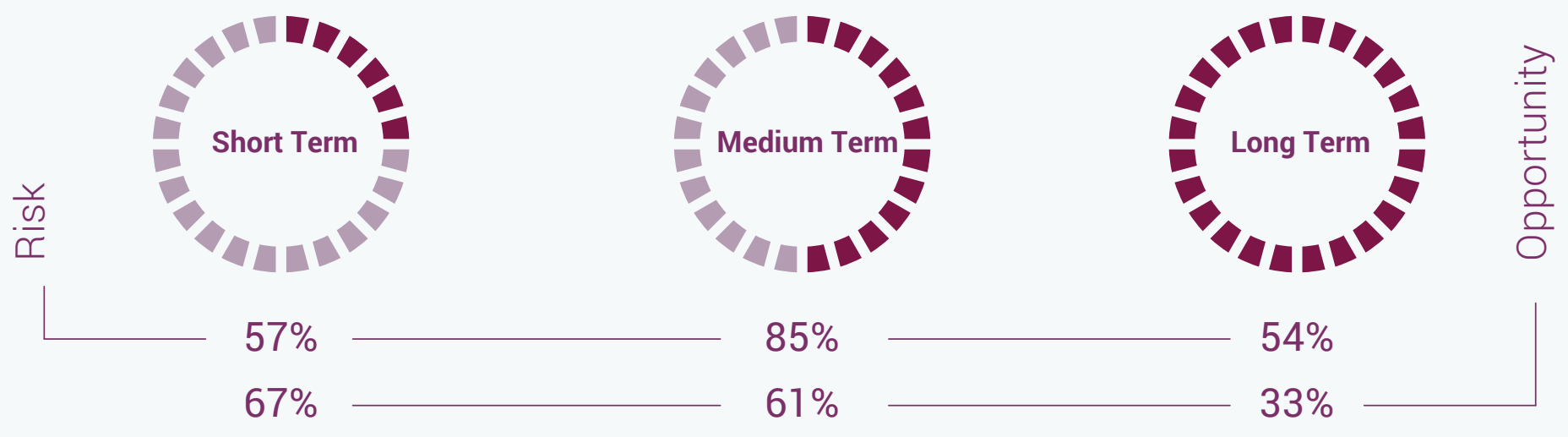


Aligning climate action with climate science: Setting a science-based target

A growing number of companies are aligning their emissions reduction goals with the Paris Agreement, by using the best available climate science to set $\mathrm{GHG}$ reduction trajectories in line with what would be required to hold global warming well below $2^{\circ} \mathrm{C}$ above preindustrial levels, and pursuing efforts to limit it to $1.5^{\circ} \mathrm{C}$. There are now more than 1,000 companies are working with the Science Based Targets initiative (SBTi) - a partnership between CDP, UN Global Compact, the Word Resources Institute, and WWF - to reduce their emissions in line with climate science. Science-based targets (SBTs) provide a clear framework for best practice target setting by specifying how much and how quickly a company needs to reduce its GHG emissions across scopes. Using the most recent climate science, the science-based target setting methods determine a company's share of the remaining global carbon budget based on company attributes such as their sector and provide a pathway to companies by specifying how much and how quickly they need to reduce their GHG emissions.

\section{Targets and Performance}

In Turkey, $80 \%$ of responding companies have an emissions reduction target that was active in the reporting year. A further $26 \%$ undertake both absolute and intensity reduction targets and the most commonly reported emissions reduction target type is intensity target $(37 \%)$ in 2020 . One-fifth (20\%) of responding companies have no targets in place.

There has been significant improvement in recent years in the number of companies setting targets for emissions reductions, but these targets are in many cases unambitious in their time horizon. About $35 \%$ of intensity targets and $19 \%$ of absolute targets adopted by companies are short-term i.e. till 2021. Those with a mid-term perspective (2022-2030) have mostly gone for intensity targets (37\%) with only $4 \%$ of companies setting an intensity target for 2031 and beyond. Most companies do not have a long-term vision to reduce their emissions.

13 percent of companies in Turkey report that they have achieved their current intensity targets by completing their targets $100 \%$ in the reporting year but the majority of the reported targets are still underway (37\%).

Focusing on the absolute targets, which are crucial to drive companies' emissions reductions no matter their changes in output or in size, $19 \%$ of companies report in detail about absolute targets underway (15 targets in total). $17 \%$ have targets expiring between $2020-2025$ and only $6 \%$ have in place long-term targets beyond 2025 and out towards the middle of the century.

To deliver against their targets, global companies are increasingly turning to clean energy, cutting emissions while simultaneously increasing their energy productivity, and reducing their energy use. In Turkey, $11 \%$ of companies have an energy consumption or efficiency target. Targets for replacing existing energy sources with renewable energy should be a part of the company strategy, but now, few companies in Turkey have set these types of targets. $19 \%$ of companies have set a renewable energy consumption target, while $9 \%$ have set a renewable energy production target.

\section{$80 \%$}

\section{have an emissions} target that was active in the reporting year

Arçelik aims to continue having net-zero carbon emissions by eliminating the total eCO2 emissions of its domestic production plants in Turkey until 2040 by implementing new energy efficiency projects (emission reduction projects), using the electricity generated from renewable energy sources and carbon offsets. Arçelik's first target year to meet this goal is 2025 but, Arçelik also aims to continue this target in the long term. Thanks to energy efficiency studies and the supply of electricity produced by renewable energy sources, Arçelik has reduced GHG emissions by $50.49 \%$ compared to the base year 2010.

\section{Types of targets based on time-frame of target year}

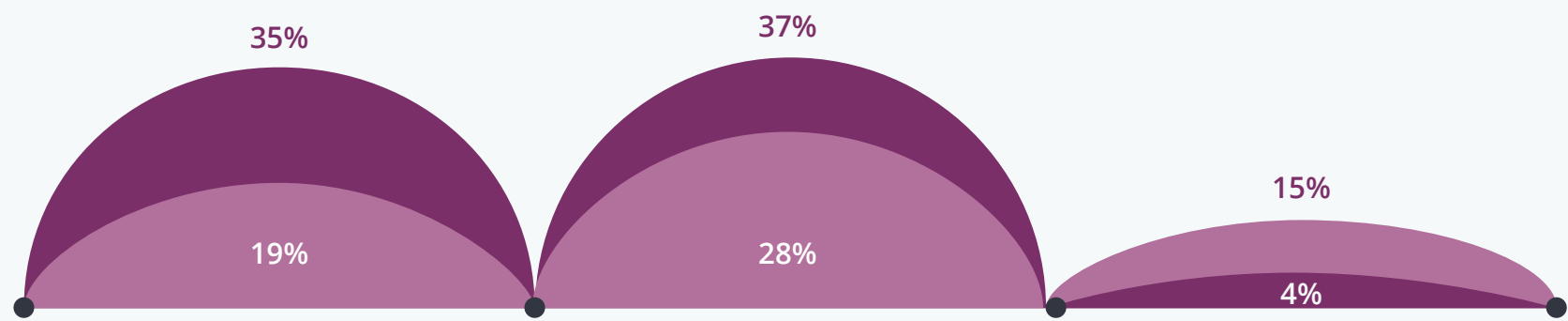

till 2021 


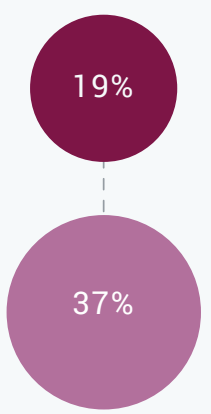

Underway

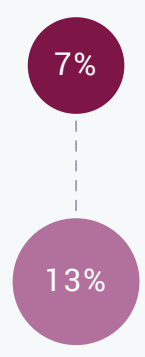

Achieved

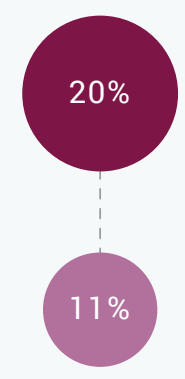

New

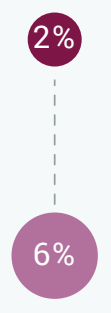

Revised

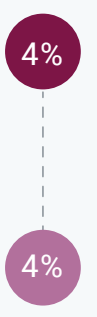

Retired
$0 \%$

$\circ$

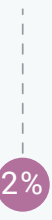

Replaced

\section{$33 \%$}

\section{anticipate setting} science-based

\section{emission reduction} targets in the next two

\section{years}

In addition to energy efficiency projects

like automation and natural cooling

systems, Migros plans to install PV

panels on the top of Torbalı and Adana

distribution centers and conduct a study

to feasibility of this project accordingly.

This system will save $30 \%$ of electricity

consumption used in these facilities.

As a first step for turning electricity

consumption to more green way, Migros

decided to purchase carbon offsets in

size of $38,000 \mathrm{MWh}$ electricity which is

equivalent to $6.72 \%$ of total electricity

consumption.
Number of companies adopting Sciencebased targets is very limited in Turkey. Only $9 \%$ of respondents consider that their target is a science-based target, but only one of these targets (the target of Kayseri Ulaşım) has been approved as sciencebased by the Science Based Targets Initiative (SBTi). However, just after the end of 2020 reporting period of CDP, Arçelik's target was approved by SBTi which means there are two companies with an approved targets in Turkey now but in this report we will reflect the results of the reporting period.

\section{Company responses on emissions}

reduction initiatives allow CDP data users to understand the organization's commitment to reducing emissions beyond business-asusual scenario. $87 \%$ of companies in Turkey report active emissions reduction initiatives in the reporting year. By improving their energy efficiency, companies aim to reduce their costs. More than half of companies (54\%) reported that the initiatives are related to energy efficiency in production processes.
Unsurprisingly, energy efficiency in buildings (48\%) comes after with a huge potential to save carbon emissions.

Half of the reporting companies (50\%) believe that their active emission reduction initiatives will payback in less than a year and for only $10 \%$ of companies, the payback period is much longer - ten years and more.

Higher low-carbon investment is also associated with ambitious voluntary emissions reduction targets in companies. $89 \%$ of low-carbon investment was made by companies that already have emission reduction targets in place. More than half of the companies in Turkey have a dedicated budget for energy efficiency (52\%), lowcarbon product $R \& D(28 \%)$ and emission reduction activities (19\%). Compliance with regulatory requirements (35\%) and engagement of employees (31\%) are other primary methods that companies use to drive investments in emission reduction activities.

\section{Science Based Target status of companies}

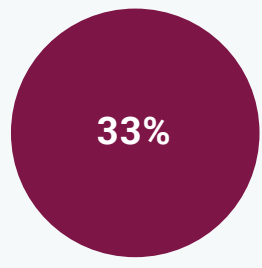

No, but we anticipate setting one in the next

2 years

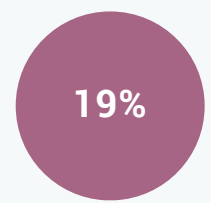

No, and we do not anticipate setting one in the next 2 years

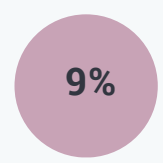

$4 \%$
Yes, we consider this a science-based target, but this target has not been approved as science-based by SBTi
No, but we are reporting another target that is science-based

\section{$2 \%$}


Top 5 initiatives implemented in the reporting year / activity type

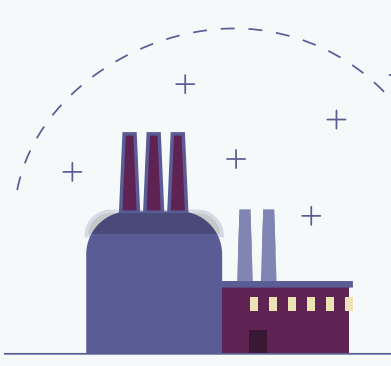

Energy efficiency

in production processes
Energy efficiency
in buildings

$48 \%$

\section{$54 \%$}

"

\section{$43 \%$}

existing products and/ or services enable third parties to avoid GHG emissions

Vakıfbank aims to start purchasing green electricity generated from 100\% renewable energy resources by Private Purchasing Agreement (PPA). Scope 2 emissions in 2019 were 32,504 tCO2e and the Bank aims to consume 10\% of our electricity consumption from electricity generated by $100 \%$ renewable energy resources. It will lead an emission reduction of 3,250 tCO2e.
Questions on low-carbon products provide valuable information to investors who are seeking to increase their investment in companies providing lowcarbon and climate resilient goods and services. $43 \%$ of companies report that their existing products and/or services enable third parties to avoid GHG emissions. A further $19 \%$ are also working to reduce downstream emissions through providing low carbon products and/or services that can help their customers reduce emissions.

\section{$87 \%$ \\ have active emission reduction initiatives}

ASELSAN aims to be one of the

main producers of renewable energy

technologies and low carbon products

in Turkey in the mid- term. The Electric

Vehicle Systems Program Management

Department started an R\&D project

with TEMSA in March 2015 with the

aim of producing the first domestic

electric buses. As transportation-related

GHG emissions account for nearly

$14 \%$ of Turkey's total emissions, it is

aimed to supply necessary electric

vehicle systems designed for public

transportation for major municipalities of Turkey.

\section{Top 5 methods to drive investment in emissions reduction activities}

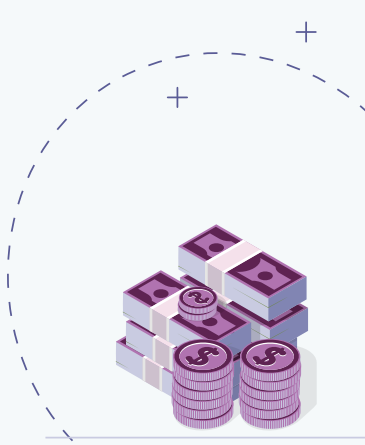

Dedicated budget for energy efficiency
Compliance with regulatory requirements/ standards
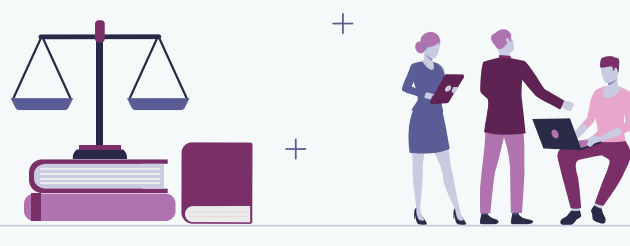

Employee engagement

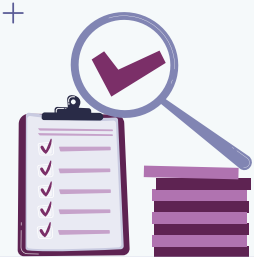

Dedicated budget for low-carbon product $R \& D$

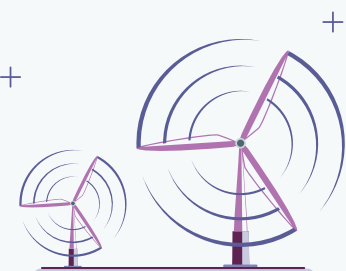

Dedicated budget for other emissions reduction activities 


\section{$93 \%$}

\section{reported scope $1 \& 2$ emissions}

\section{$70 \%$}

Scope $1 \& 2$

emissions have been

externally assured

or assurance is

underway

\section{$46 \%$}

energy consumption

totals from renewable

\section{sources in $\mathrm{MWh}$}

Coca Cola içecek's total direct and

indirect energy use, arising from

stationary and mobile diesel, LPG

combustion, stationary natural gas

consumption (heating) and mobile

gasoline combustion (company cars)

and electricity use in 2018 was 265,186

MWh. Energy consumed for the same

items is $268,927.29 \mathrm{MWh}$ in 2019. This

increase is in line with the increase in our

production volume which is $1.41 \%$ as well.

In 2018, with the help of 22 Operational

Excellence projects conducted in Turkey,

US\$88.2 thousand is saved. In other

words, Cola Cola İçecek saved 7.3 Million

$\mathrm{MJ}$ of energy and reduced 577,8 tons of

CO2e by means of our efficiency projects conducted in Turkey Operations.
Tracking progress: Emissions trend \& verification

Measuring and reporting progress is key to ensuring companies are reducing negative environmental impacts and contributing to a sustainable economy. This initial disclosure process is vital to understand exactly where and how they operate today and use this as a baseline to set more informed targets. In total $93 \%$ of companies from all sectors reported their Scope 1 \& Scope 2 emissions. A further $87 \%$ also reported their Scope 3 emissions up from $84 \%$ in 2019.

Where year-on-year comparison has been possible, there has been evidence of demonstrable progress, with a majority (65\%) of companies reporting a reduction in emissions. Annual reductions of responding companies in Turkey in Scope 1 emissions amount to the equivalent of 4.4 million tonnes of carbon dioxide. Where reductions were achieved, these were supported in $80 \%$ of companies by the implementation of proactive emissions reduction activities, such as energy efficiency projects. However, $26 \%$ of companies reported that they made absolute increases in emissions over the past year. Increased emissions are not necessarily a sign of poor progress on climate change. Of those businesses that did report emissions growth was mostly related to an overall increase in output and changes in measurement methodology.

\section{Third-party verification and assurance} ensure the quality of data and processes disclosed. A growing number of companies in Turkey recognize the importance of verifying the accuracy of their emissions data. $70 \%$ of responding companies in Turkey indicated that their Scope 1 \& Scope 2 emissions have been externally assured or assurance is underway. Since Scope 3 emissions are often more difficult to quantify when compared to Scope 1 and Scope 2 emissions, the level of the third-party verification is comparatively lower in this area: $41 \%$.

Energy-related activities represent the most significant GHG emission sources. Accurate emissions accounting depends on a comprehensive account of energy. Consumption of fuel and consumption of purchased/acquired electricity are the top two energy-related activities that the companies have undertaken in Turkey.
Almost all companies (94\%) provide energy consumption totals (158 million MWh excluding feedstock) including energy consumption totals from renewable sources (46\%) - 3.3 million MWh in total. A further $74 \%$ provides fuel consumption totals by fuel type consumed by the company.

Operational spend on energy is a strong indicator for a company to investigate opportunities to reduce cost while ensuring emission reductions through the adoption of low carbon energy options. In Turkey, only $9 \%$ of responding companies have reported that more than half of their total operational spend was on energy (electricity, fuel, etc.).

Gross global emissions (Scope 1 and 2 combined) for the reporting year compare to those of the previous reporting year

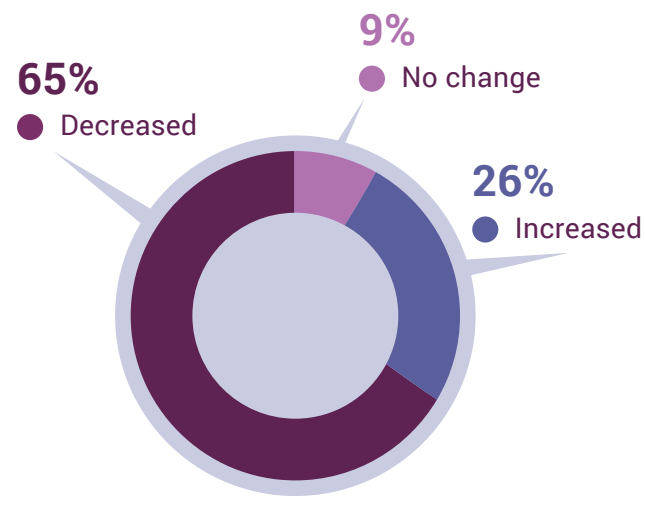

GHG emissions of Vestel Beyaz per revenue decreased by $17.81 \%$ in 2019 The main reason for this decrease is energy reduction activities and increase in revenue compared to previous year. 
Brisa's ultimate long-term aim as a measure of success is to gradually increase the number of suppliers and reach $100 \%$ of our supply chain and have their commitment to the procurement policies on a local level. Via introduction of Bridgestone Global Sustainable Procurement Policy, all strategic suppliers have committed to comply with the Global Policy, which enables the company to identify and manage supply chainrelated environmental risks and impact so the necessary measures will be applied to improve supply chain performance as well as resilience with regards to climaterelated negative impacts. In addition to global strategic suppliers, Brisa also aims to engage with suppliers that are not covered by the Bridgestone Global Sustainable Procurement Policy. As a result of this engagement, $26.5 \%$ our Brisa-specific suppliers with the number of 5,762 have confirmed their compliance with Brisa's Responsible Procurement Policy in 2019.

\section{Vngagement with stakeholders}

It is imperative for a business to engage and communicate effectively with its stakeholders to be better prepared for climate change. Cross-sectoral and public-private engagement contributes more to climate action, increasing mobilization towards innovation and resources to make progress on a larger scale. Collaborating with the value chain can help ensure incorporation of emission reduction activities throughout the lifecycle of the product, considering both upstream and downstream emissions.

More companies in Turkey are engaging with key stakeholders such as policymakers, suppliers, and customers: $89 \%$ (53\% in 2019$)$ of companies engage with their value chain on climate-related issues but only $30 \%$ engage with more than half of their suppliers by number.

Most of the reporting companies (91\%) engage in activities that either directly or indirectly influence public policy on climate-related issues. Some engage directly with policy-makers, while others do it through trade associations and research organisations. The percentage of companies sitting on the board of any trade associations or provide funding beyond membership is $52 \%$.

87 percent of companies published information about organization's response to climate change and GHG emissions performance for this reporting year in places other than CDP response. A further $52 \%$ published voluntary sustainability report. Companies should be aware that their financial reporting is expected to include environmental information at the same level of CDP responses according to TCFD recommendations.

\section{$89 \%$}

engage with key stakeholders on climate-related issues

\section{$30 \%$}

engage with more than half of suppliers to drive emission reductions

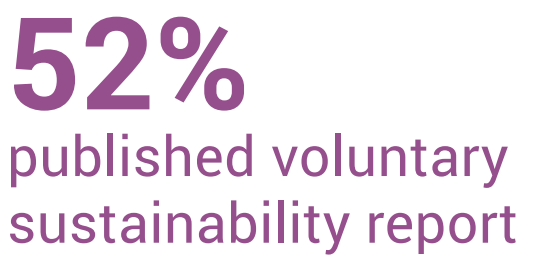

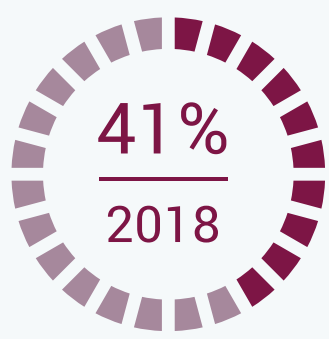
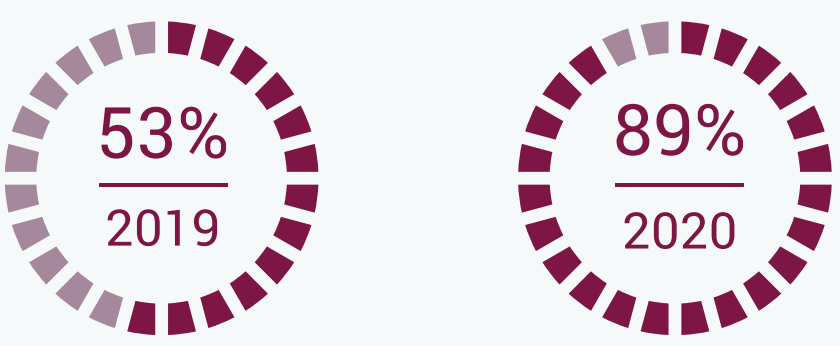


\section{A GLIMPSE INTO THE LAST 10 YEARS}

\section{CLIMATE CHANGE /TURKEY 2020}

Completeness of submission (75-100\%)

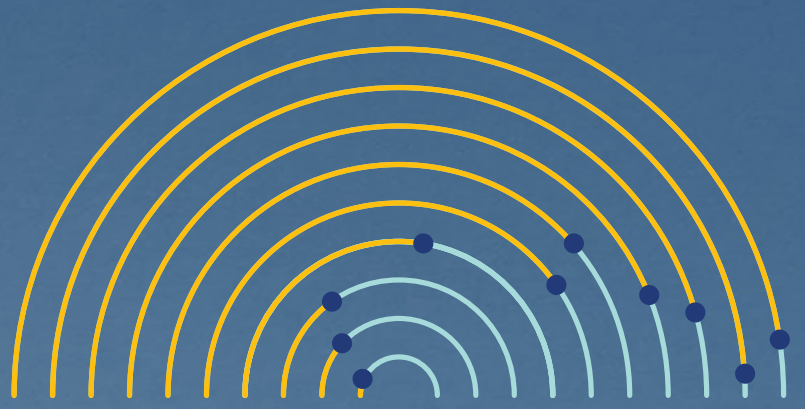

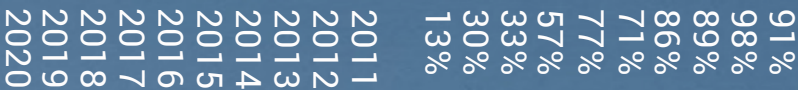

Reported score 1 \& 2 emissions

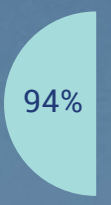

2011

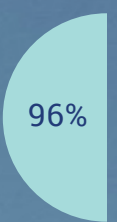

2012
Board-level oversight of climate-related issues

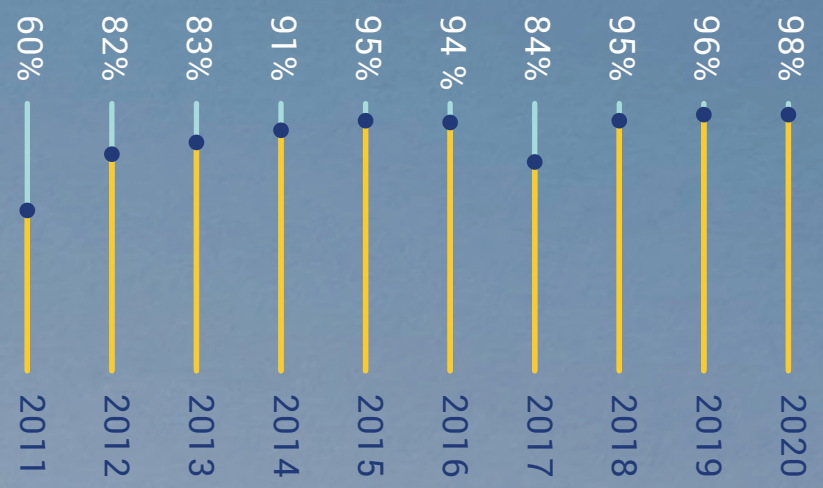

Total Responding Companies
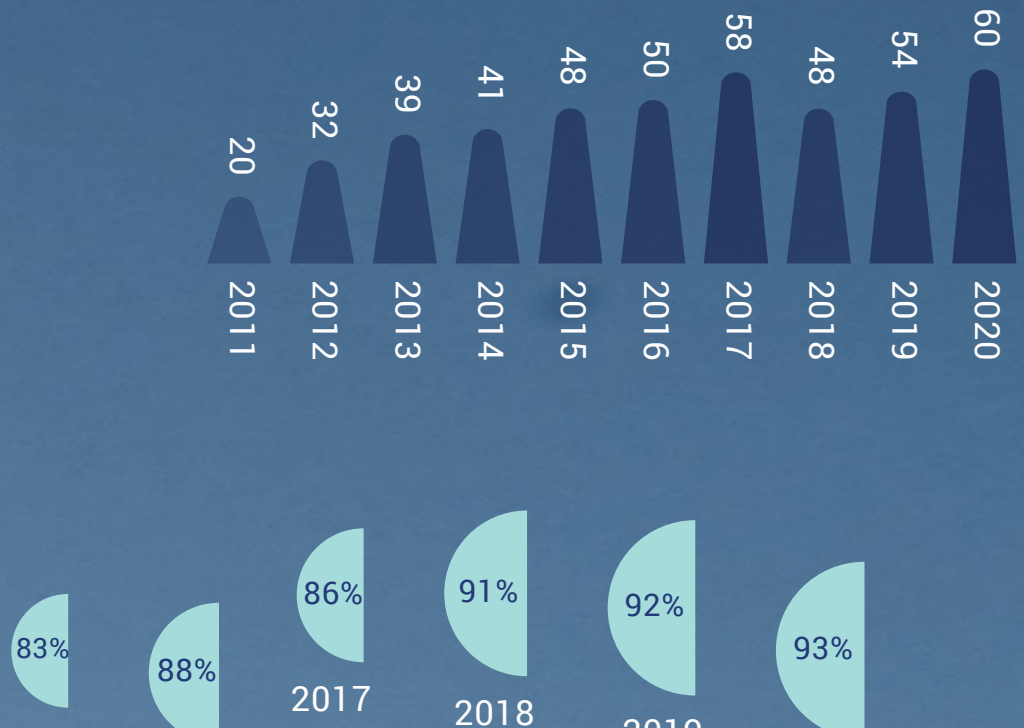

$88 \%$

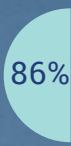

2017
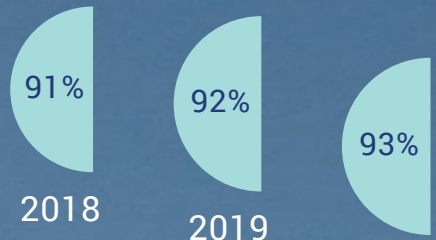

2016

2020

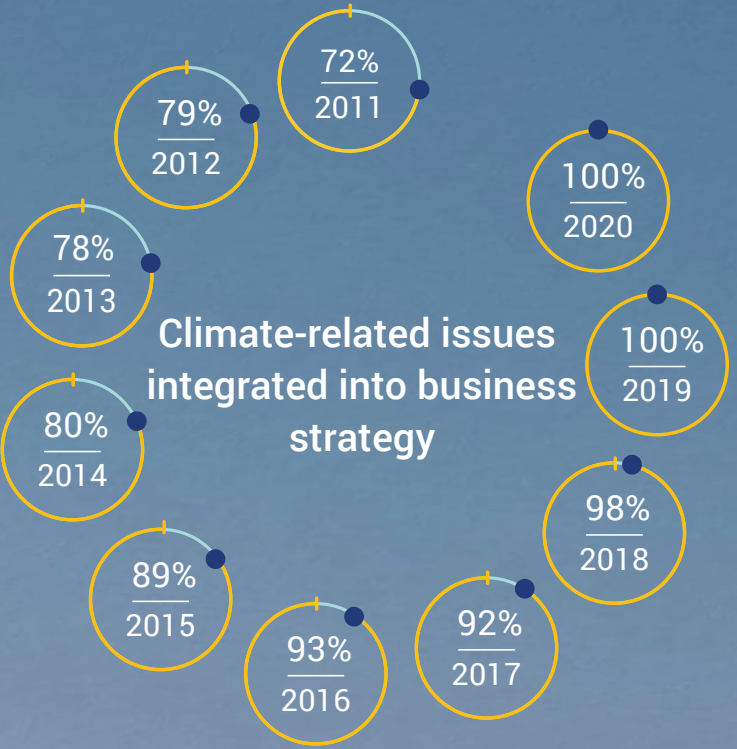

Identified any inherent climate-related risks with the potential to have a substantive financial or strategic impact on the business

\begin{tabular}{|c|c|c|c|c|c|c|c|}
\hline $89 \% \quad 100 \%$ & $89 \%$ & $91 \%$ & $88 \%$ & $91 \%$ & $94 \%$ & $93 \%$ & $90 \%$ \\
\hline$\equiv$ & 르 & 르 & 르 & $\equiv$ & 르 & 플 & 르 \\
\hline$\equiv$ & 를 & 믈 & 를 & 믐 & 三 & & \\
\hline 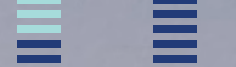 & 트 & 름 & 플 & 를 & 三 & $\equiv$ & : \\
\hline & $\equiv$ & $\equiv$ & $\equiv$ & $\equiv$ & 三 & $\equiv$ & $=$ \\
\hline$E$ & $\equiv$ & $\equiv$ & $\equiv$ & $\equiv$ & $\equiv$ & $\equiv$ & E \\
\hline$\equiv$ & $\equiv$ & $\equiv$ & $\equiv$ & 三 & $\equiv$ & $\equiv$ & $\equiv$ \\
\hline & & & & & & & \\
\hline
\end{tabular}


Provide products and/or services that enable a third party to avoid GHG emissions

\begin{tabular}{|lllllllll}
$56 \%$ & $64 \%$ & $50 \%$ & $51 \%$ & $56 \%$ & $49 \%$ & $40 \%$ & $24 \%$ & $43 \%$
\end{tabular}

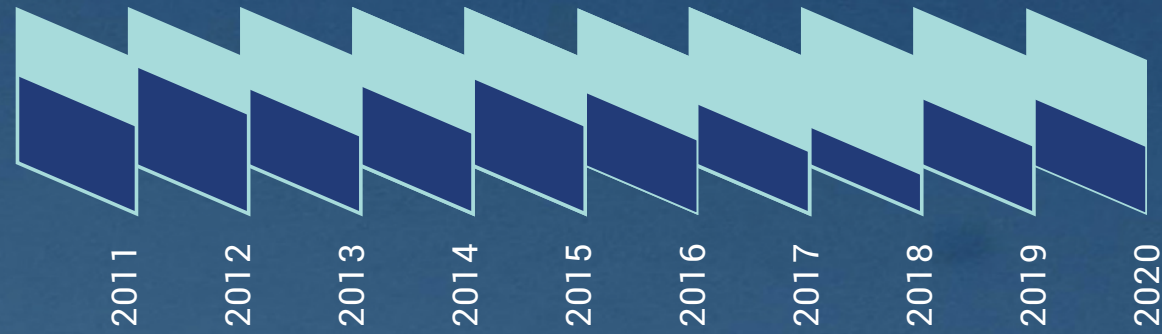

Reported decrease in Scope 1 \& 2 emissions from previous year

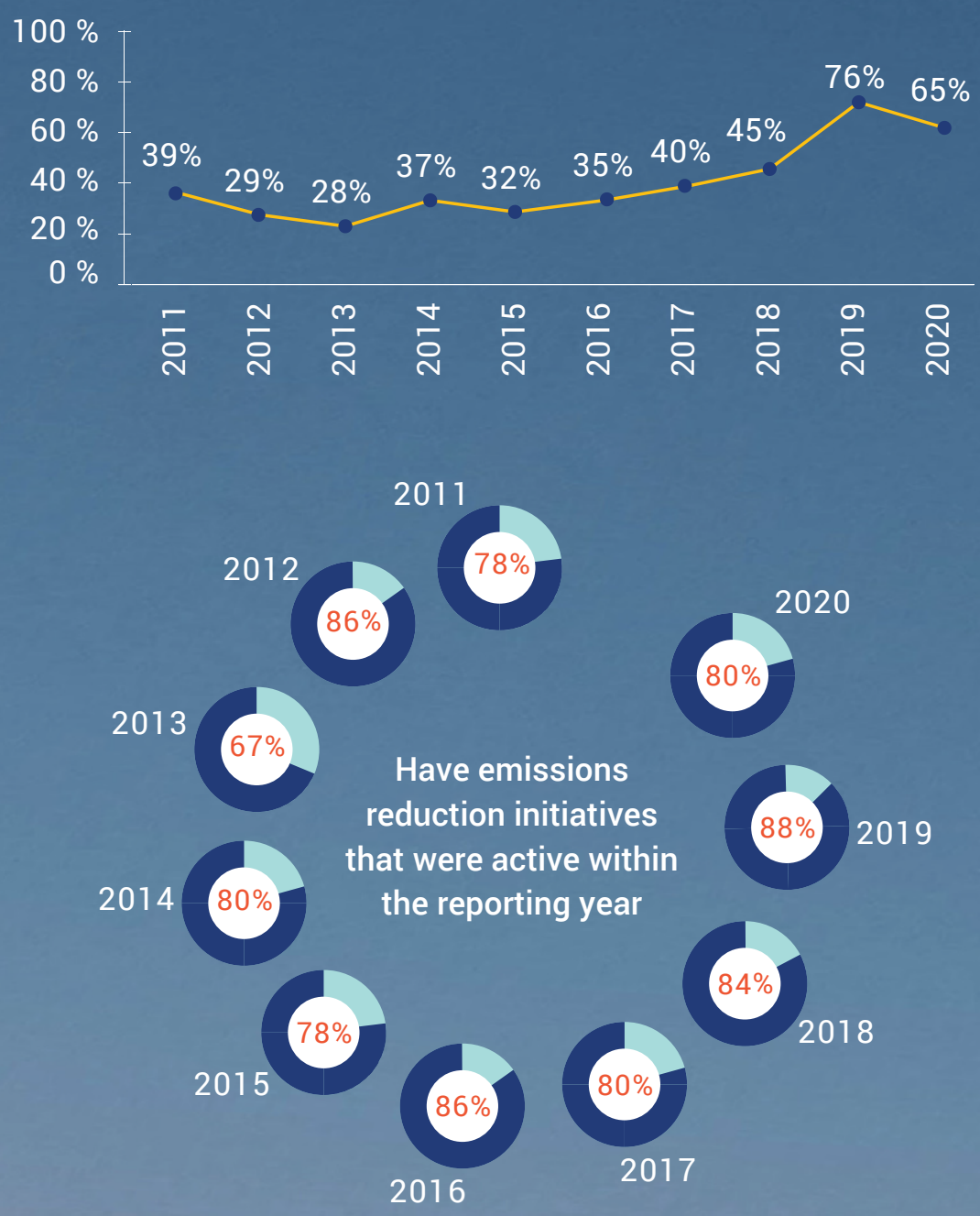

\section{Reported Scope 3 emissions}

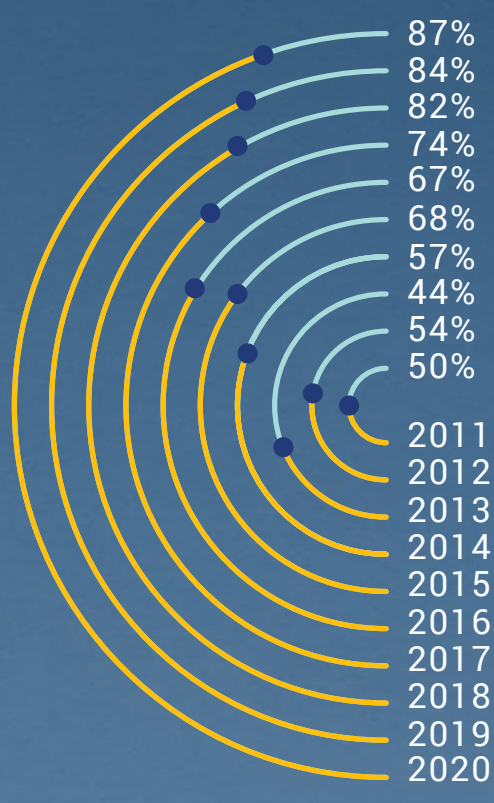

Published information about organization's response to climate change and GHG emissions performance

Provide incentives for the management of climate-related issues

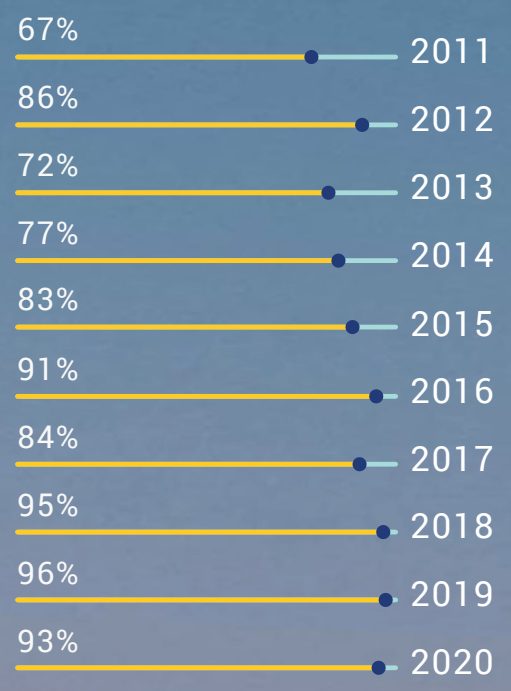




\section{COMPANY RESPONSE SUMMARY WATER SECURITY / TURKEY 2020}

\section{GOVERNANCE}

This module captures the governance structure and mechanisms of the organization concerning water security. It provides data users with an understanding of the organization's approach to water-related issues at the board-level and below the board-level.

v $\mathbf{9 7 \%}$ have a board-level oversight of water-related issues within the organization

\ $\mathbf{8 2} \%$ have a company-wide water policy

v $\mathbf{5 6 \%}$ reported that CEO is the individual on the board with responsibility for water-related issues

\section{VERIFICATION}

CDP data users often ask about the credibility/quality of data disclosed. The information requested in this question could help strengthen confidence in the organization's response to the water security questionnaire. CDP supports the development and use of verification methodologies as it promotes good practice in environmental disclosure.

- $\mathbf{5 0} \%$ of the respondents verified water withdrawals

V $\mathbf{4 1 \%}$ of the respondents verified water consumption

V $41 \%$ of the respondents verified water discharge

- $\mathbf{1 8 \%}$ of the respondents verified water recycled/reuse

\section{OPPORTUNITIES}

The structure of the water security questionnaire allows a company to tell investors, customers and other data users about its water stewardship journey. For this reason, CDP invites companies to share any water-related operational or market opportunities being realized that could substantively benefit their business. With this module, data users understand the current state of a company's use of water and how water-related opportunities are identified.

- $\mathbf{8 8} \%$ of the respondents identified water-related opportunities with the potential to have a substantive financial or strategic impact on the business.

Primary water related opportunities currently being realized that could have a substantive financial or strategic impact on the business:

\section{BUSINESS STRATEGY}

This module aims to collect information on how a company is adapting its long-term business model to secure a sustainable future, in terms of both its resilience and securing water for all.

$\mathbf{8 5} \%$ of the respondents monitored targets and goals at the corporate level

v $\mathbf{5 6} \%$ of the respondents identified any water-related outcomes from the organization's climate-related scenario analysis

V $\mathbf{5 0}$ of the respondents identified reduced environmental impacts as primary motivation behind the water related targets

च $\mathbf{1 8 \%}$ of the respondents use an internal price on water

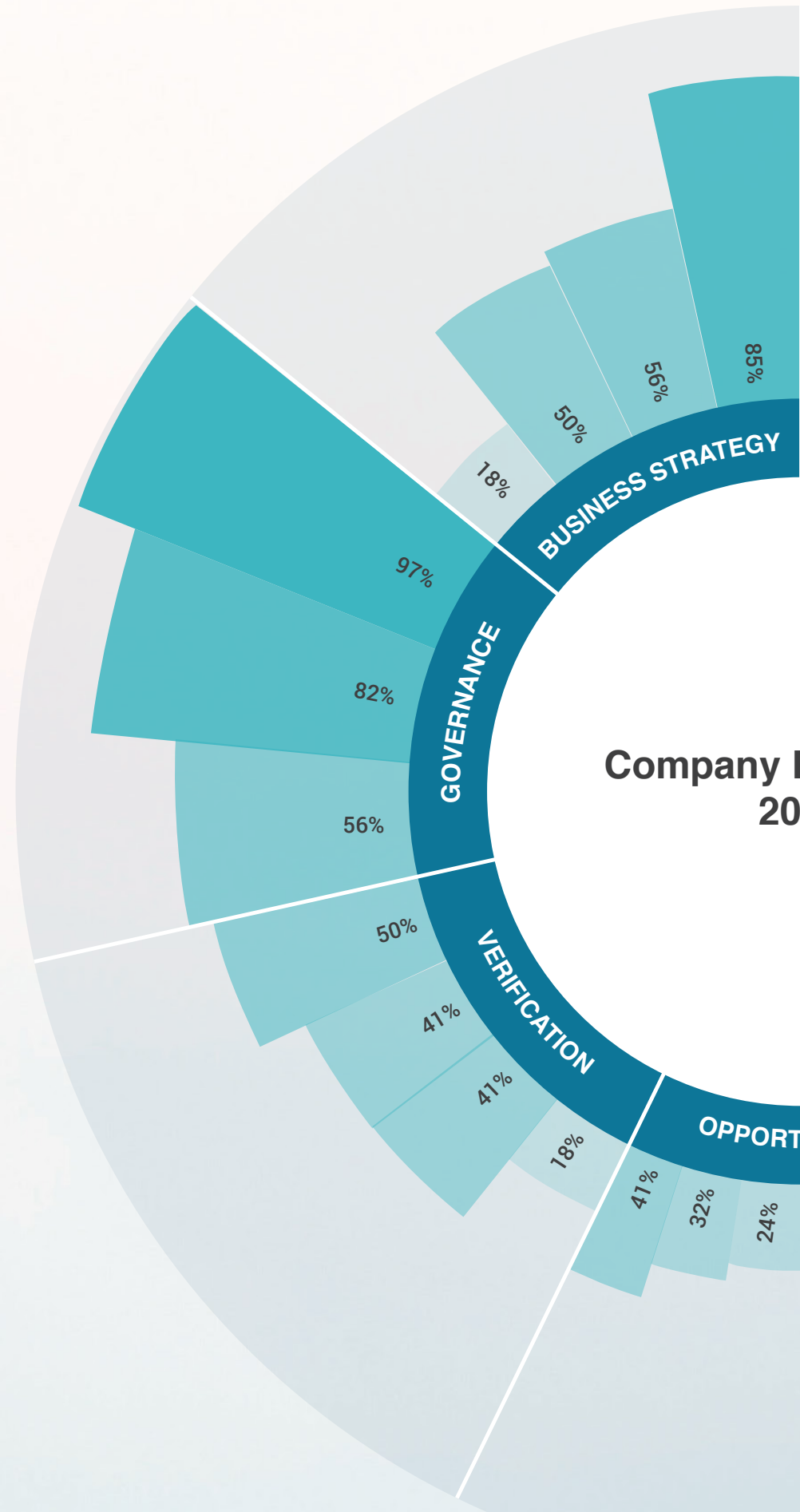




\section{CURRENT STATE \& ACCOUNTING}

This module allows CDP data users to build a picture of the dependence of the company's direct operations and value chain on the water of a particular quality and to see where in the value chain dependence on water lies the most. The questions allow companies to demonstrate how well they understand their corporate hydrology by providing information on the monitoring of relevant water aspects, and volumetric data on withdrawals.

च $\mathbf{8 8} \%$ regularly measured and monitored all of the water aspects across all operations

V $\mathbf{7 1 \%}$ of total water withdrawal sourced by third party sources

V $\mathbf{5 3}$ \% reported that more than half of total withdrawals sourced from water-stressed areas

च $\mathbf{2 4 \%}$ of the respondents request from more than half of suppliers to report on their water use, risks and/ or management information

\section{BUSINESS IMPACTS \& PROCEDURES}

This module focuses on water-related impacts on organization and response to them. These are impacts that have occurred in the past reporting year, including those resulting from regulatory violations. Procedures module requests information about the procedures that organizations have in place to manage issues salient to their sector and to understand inherent risk exposure.

V $71 \%$ assessed water-related risks for more than 6 years

$\checkmark \mathbf{4 4 \%}$ assessed water risks as part of the other company-wide risk assessment systems

V $\mathbf{3 5 \%}$ have procedures for identifying and assessing water-related risks covered both direct operations and supply chain

च $\mathbf{9} \%$ of companies stated that flooding is the most reported impact driver of the water-related detrimental impacts experienced by the company

\section{RISKS}

A better understanding of the number, location, and nature of inherent water risks is valuable for disclosing companies, as well as CDP data users. This module allows companies to show that they have a clear awareness of the extent to which they are exposed to inherent water risks in their direct operations and other parts of their value chain.

$\mathbf{7 9} \%$ of the respondents identified inherent water-related risks with the potential to have a substantive financial or strategic impact on the business.

\section{Potential impacts of identified risks in the direct operations are:}




\section{6}

\section{disclosing companies in total}

\section{$50 \%$}

\section{water quality \& quantity is vital for the success of the business}

Stakeholders are calling for accessible, accurate and comprehensive information that demonstrates responsibility for reducing water-related risks and impacts. CDP's water security questionnaire provides a valuable platform to facilitate this transparency and dissemination of information and tracks key performance indicators such as corporate governance, risk management and value chain engagement in order to provide consistent, quantifiable, and comparable data and insights to investor shareholders and purchasing organisations. These insights are then used to make smarter, more informed investment and purchasing decisions. In 2020, more than 2500 companies disclosed on water through CDP, with this data shared with 515 investors, representing over $\$ 106$ trillion in assets and more than 150 purchasing companies.

On behalf of investor signatories, in the sixth year of the CDP Water Program in Turkey, we asked 50 companies to provide data about their efforts to manage and govern water resources. We selected these companies based on economic and environmental indicators (largest listed companies in high water impact industries). In total, $\mathbf{3 6}$ companies responded to CDP's water program in Turkey up from 32 companies (13\% increase) in 2019. Out of 36 respondents, 15 were self-selected (SSCs) and 21 were included in the Turkey sample that received an official invitation. Therefore, the response rate of the official sample is $42 \%$ (34\% in 2019).

This chapter presents summary findings from our analyses of (two of the companies are See Another Company) responding company disclosures in response to the CDP Water Information Request.

\section{$\checkmark$ Current State and Accounting}

Disclosing through CDP allows companies to build trust and credibility by providing information directly to investors and customers, using a market-leading and standardized disclosure system. This process enables companies to demonstrate their involvement in the reporting progress against a comprehensive set of water stewardship indicators. Robust water accounting data is necessary to inform business planning and forecasting as well as risk identification and response.

Measuring and monitoring water usage, discharge and consumption are vital first steps in enabling companies to understand the risks they face, and the opportunities available to improve water security and stewardship throughout their operations and supply chains. This module allows CDP data users to build a picture of the dependence of company's direct operations and wider value chain on sufficient amounts of water of a particular quality, currently and for future growth, and where in the value chain most dependence on water lies.

Water quality and quantity has a vital importance for Ford Otomotiv's direct operations. The direct use of water resources is vital for operations' continuity such as vehicle painting in manufacturing processes, machining of power train components, cooling towers, wash services. As a large purchaser of parts, materials, components, the indirect use of water has an importance for operations and services performed by suppliers in current and future conditions. Pollution or salinization of the water resources may pose some risks in water availability causing increases in the operational costs. For this reason, Ford Otomotiv prefers using water efficiently. Reducing water usage by monitoring water quantity and quality is always in their concern. 


\section{The importance (current and future) of water quality and water quantity to the success of business}

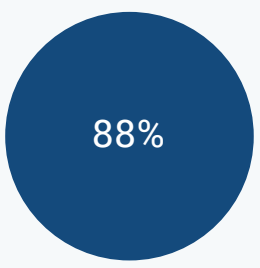

Sufficient amounts of good quality freshwater available for use is "vital" or " important" for the direct operations

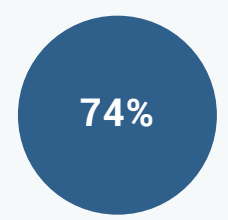

Sufficient amounts of good quality freshwater available for use is "vital" or " important" for the indirect operations

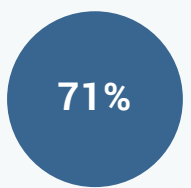

Water quality \& quantity is important for the success of the business
$50 \%$ $9 \%$

\section{$44 \%$}

water withdrawals is lower than the previous year

\section{$52 \%$}

more than half of total withdrawals sourced from water stressed areas
The availability of sufficient amounts of good quality freshwater is vital for health, livelihoods, ecosystems and economic production. Therefore, CDP asks companies to rate the importance of water quality and water quantity to the success of their business. The companies disclosing from Turkey report that having sufficient good quality freshwater for their own use is either important $(71 \%)$ or vital (50\%) for their business.

Responding to risks and seizing opportunities requires awareness, monitoring, transparency and disclosure. A significant portion of responding companies (91\%) reporting via CDP now measure and monitor more than half of all water aspects across all operations (sites/facilities/operations). A further $88 \%$ are regularly measuring and monitoring all water aspects. $56 \%$ of responding companies also ask their key suppliers to report on their water use, risks and/ or management information. $24 \%$ are requested that information from more than half of their suppliers.

As per accounting of water use, $88 \%$ of responding companies in Turkey gave an account of their water withdrawals by source via CDP. Total volume of water withdrawn across all operations is 4,223 megaliters. A further $85 \%$ also provided total water discharge data by destination that is 3,844 megaliters in total.

Percentage of companies require suppliers to report on their water use, risks and/or management information

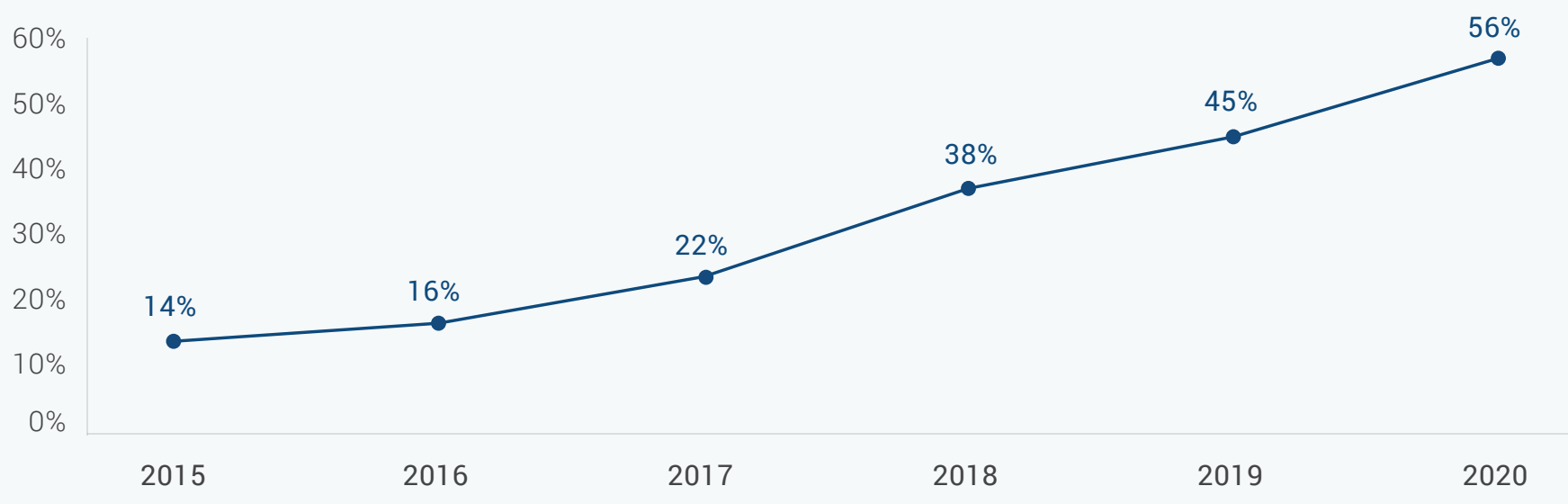




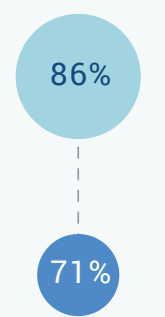

2015

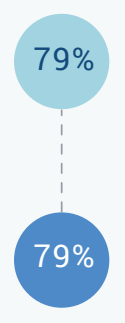

2016

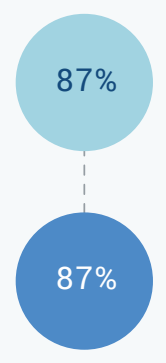

2017

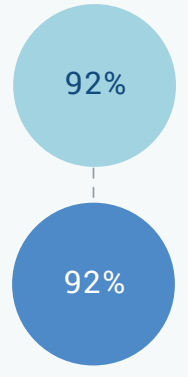

2018

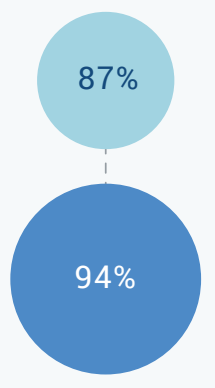

2019

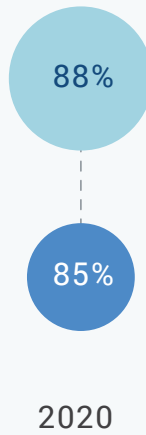

2020

Total water discharge data by destination $\square$ Total water withdrawal data by source

\section{$71 \%$}

water withdrawal is sourced from third party sources

\section{$76 \%$}

\section{engage with the value chain on water-related} issues
Most companies try to reduce their water consumption through recycling and reusing. But the above figures prove that despite these efforts the demand for water in industrial activities is still not decreasing. While $29 \%$ of responding companies have measured that, their water consumption is lower than the previous year, $32 \%$ report an increase. In terms of water withdrawals, $44 \%$ of responding companies report a decrease, while $29 \%$ measured an increase compared to previous year. The most common explanation that companies provide for increased withdrawals is an increase in production. $38 \%$ of companies reported that total water discharge by destination is lower compare to the previous year.

53 percent of responding companies reported that more than half of total withdrawals are sourced from water stressed areas which is much higher

\section{Percentage of companies providing total volumes of water}

withdrawn, discharged, and consumed across all operations compare to the previous reporting year

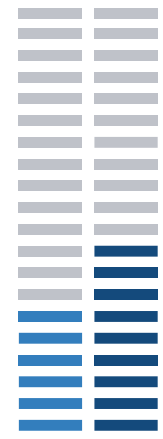

$29 \% 44 \%$

Total Withdrawal

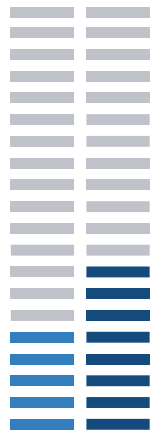

$26 \% 38 \%$

Total Discharge

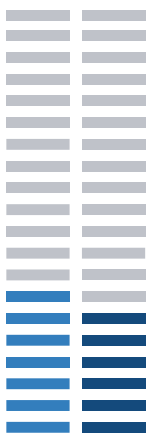

$32 \% 29 \%$

Total Consumption compare to the previous year (39\%). Most of the water withdrawal is sourced from third party sources $(71 \%)$ and most of the water is discharged to third party destinations (76\%) which shows water crosses the company boundary, at either the corporate level or facility level.

The module also asks about engagement activity around water in the value chain and a rationale for it. In regions where water sources are highly restricted, organization's water consumption patterns can influence relations with other stakeholders and access to water can be dependent on those relationships. $76 \%$ of responding companies engage with the value chain on water-related issues.

Half of the responding companies in Turkey externally verified their water withdrawals data. Water consumption (41\%) and water discharge (41\%) are the next most externally verified water accounting data. A further $32 \%$ verified other water information besides the water consumption, discharge, withdrawal and recycle/reuse data.

Coca Cola's water withdrawal from water-stressed areas was $24 \%$ last year and this year the ratio increased by only $1 \%$ when calculated over the production volumes of plants located in high water-stressed areas, and the ratio turned $25 \%$. Source Vulnerability Assessment Study is conducted by professional and independent third party consultancy firms for each plant. According to CCl's 'Source Water Protection Plan' water-stressed areas are determined with a comprehensive research study and water stress is determined up to date for each plant and the plants are categorized accordingly: Çorlu and İzmir plants are in water stress areas. 


\section{$26 \%$}

\section{experienced detrimental water related impacts}

The total damage of the severe weather events was the damage due to loss of crops. Unfortunately, due to the nature of farming, there are not many measures to implement to be resilient to such acute and severe physical events. However, Tekfen Holding makes sure their employees and facilities are well equipped to take immediate action to protect and maintain our business as usual operations. While this response is not directly linked to water security, it is caused by the changing climate/precipitation patterns and is considered as a chain in the water cycle. Tekfen's response to all incidents is to secure operations with minimum or if possible no disruption, which includes maintaining our water security and resilience. As an example of these preventive measures, they have installed hail nets to protect products (stone fruit) against a potential hail covering a 330 decares of our Alanar Fruit orchard. By doing so they minimized the risk of heavy precipitation-related detrimental impact.

\section{Business Impact \& Procedures}

There are financial risks that companies face from water issues. $26 \%$ of companies in Turkey suffering from some sort of waterrelated issue (experienced detrimental impacts) over the reporting periodmostly related to flooding or droughts. Companies should act on their water security because the price of non-action is high. Total financial impact of waterrelated detrimental impacts experienced by companies in Turkey is US\$26.5 million.

\section{The most frequently cited impact drivers are:}

- Flooding: 9\%

- Drought: $6 \%$

- Inadequate infrastructure: $6 \%$

- Severe weather events $3 \%$

- Declining water quality: $3 \%$

A comprehensive risk assessment is essential for companies to develop a clear understanding of physical, regulatory, and reputational exposures as well as opportunities available. $91 \%$ of responding companies state that water risks are assessed. However, waterexposed companies should conduct risk assessments that are company-wide and comprehensive, including their direct operations and their supply chains. $35 \%$ of disclosing companies meet this higher standard. Other $71 \%$ assessed water-related risks for more than six years.

Water-related regulatory frameworks are the most considered contextual issues in the company's water-related risk assessments. Water is also a local issue and each river basin faces distinct challenges as a function of the different water users operating there. Assessment at the basin level poses challenges for companies, given that it requires an understanding of the activities and needs of local communities and other local water users. $71 \%$ of companies in Turkey conduct risk assessment with a consideration of river basin management authorities and a further $88 \%$ with local communities. However, regulators are the most considered stakeholders (91\%) that are considered in the company's water-related risk assessments.

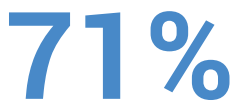

\section{assessed water related risks for more than 6 years}

When Garanti BBVA runs a project through its Environmental and Social Impact Assessment Model, one of the most important stakeholders is always the local community. Local communities are consulted as part of stakeholder engagement processes of environmental and social impact assessment. Where relevant, a Stakeholder Engagement Plan (SEP) is prepared to describe the mechanisms by which local communities and other stakeholders are informed about the Project and which gives an opportunity to provide comments and input to the Project development. Garanti BBVA's assessment model makes sure that water usage rights of downstream

communities are protected. 


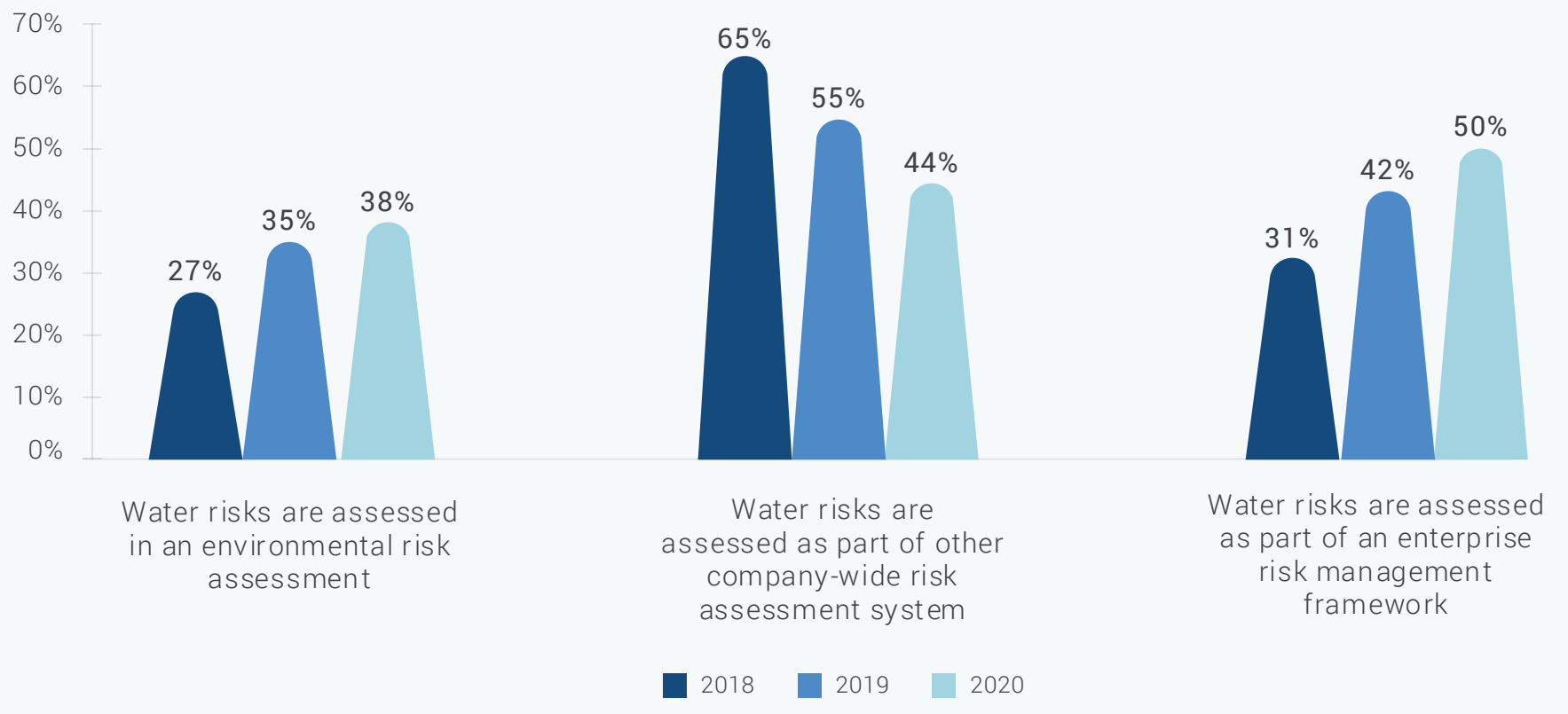

The following contextual issues are the most frequently considered ones in the organization's water-related risk assessments:

$\mathbf{8 8} \%$ Water-related regulatory

$88 \%$ frameworks

$\mathbf{8 5 \%}$ Water availability at a

Access to fully-functioning, safely

$\mathbf{8 2} \%$ managed WASH services for all employees

$76 \%$ Water quality at a basin/catchment level $\mathbf{6 5 \%}$ Stakeholder conflicts concerning water resources at a basin/catchment level

$65 \%$ Status of ecosystems and habitats

$62 \%$ Implications of water on your key commodities/raw materials

Stakeholders, which are always considered in the organization's water-related risk assessments:

$91 \%$ Regulators

$88 \%$ Local communities

85\% Employees

$82 \%$ suppliers
$82 \%$ Investors

$79 \%$ customers

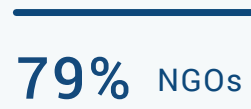

$76 \%$ Other water users at a $71 \%$ River basin management

$68 \%$ Water utilities at a local level

44\% Statutory special interest groups at a local level 
$50 \%$

\section{identified water-related}

risks both in direct

operations and the rest of the value chain

Aydem Enerji's Hydro Power Plants

are highly dependent on adequate

hydrological conditions in the

geographic regions they are located.

HPPs are exposed to droughts,

excess water, climate change and

developments in the watercourse

upstream of the relevant facility. Any

of these factors can cause volatility

in production levels and impair the

effectiveness of power plants, and

therefore can cause volatility in

profitability. For example, over the last

three years, the Dalaman HPP has been

generating approximately $40 \%$ less

power as compared to its historical

average performance in the period

between 2016 and 2018, due to the

drought in the local region.
V Risks Assessment \& Opportunities

Companies should undertake water risk assessments that account for the regional context in both direct operations and supply chains. By improving their understanding of the way in which water is managed around them, companies are better prepared to respond proactively to challenges. Therefore, CDP asked companies to report substantive water-related risks and to share any water-related opportunities being realized that could substantively benefit their business.

In Turkey, half of responding companies identified inherent water-related risks with the potential to have a substantive financial or strategic impact on the business both in direct operations and in the rest of our value chain. Other $50 \%$ of responding companies reported that more than half of companywide facilities are exposed to water risks. That percentage at the facilities on river basin is $35 \%$. Potential financial impacts of identified risks in the direct operations of companies in Turkey is US\$733 billion.

In addition to impact in direct operations, companies were also asked to assess their water risk in their value chain. Physical risks are the most reported types of risks in the direct operations (76\%) and in the value chain (38\%). Physical risks include droughts, flooding, increased water scarcity and increased water stress and so on. In direct operations, physical risks were reported mostly as a result of increased operating costs (29\%) and reduction or disruption in production capacity (15\%). Increased operating costs are also the most reported potential impact (38\%) of identified risks in the direct operations; in the value chain, the most reported risk drivers are drought (15\%) and increased water scarcity (9\%).

Assessment of impacts required the lens of timeframes and magnitude. $47 \%$ of companies anticipate that the substantive financial or strategic impacts of identified risks in direct operations will be realized within one to six years. A further $47 \%$ anticipate that it is going to realize over a period of more than six years. The chart below represents the estimated timeframe for realization of substantial financial and strategic impacts on businesses.

There are also positive opportunities identified from taking action on water issues. $82 \%$ of responding companies identified water-related opportunities with the potential to have a substantive financial or strategic impact on the business and stated that some/all are being realized. Efficiency (71\%) and markets (35\%) are the most reported types of opportunities currently being realized.
$77 \%$

identified physical risks in the direct operations
Brisa describes substantive financial and strategic impact as any risk

causing a daily shut-off of its

production facilities. However, in the

case of a severe weather event related damage to assets, the shut-off period

is likely to be longer. Assuming a shutoff range of 2 to 5 days for Production Facilities, Brisa is faced with the stated potential implication. The financial impact of a daily shut off of production facilities was determined as US\$1.86 million/day.

\section{$47 \%$}

anticipate risks to materialize within 1 - 6 years in direct operations
$82 \%$

identified water-related opportunities and some/ all are being realized 
Percentage of risk types identified in direct operations and within the value chain

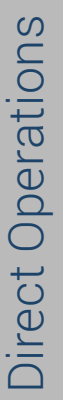

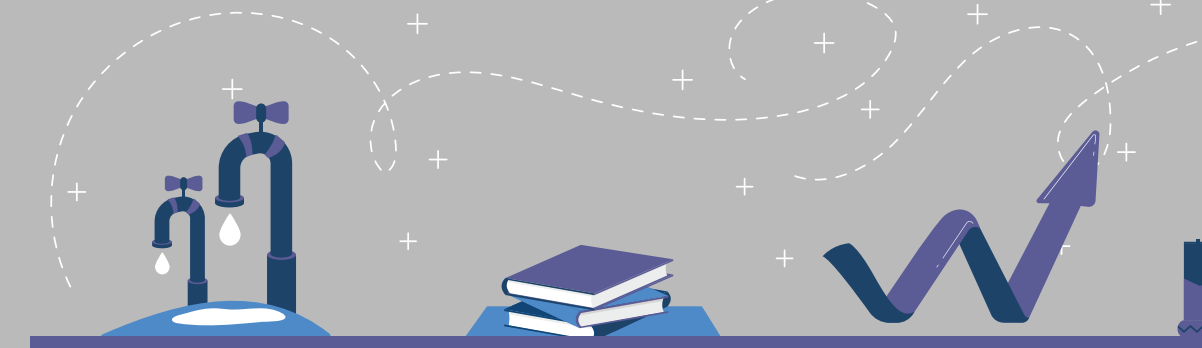

Physica

Regulatory

Reputation \& Markets

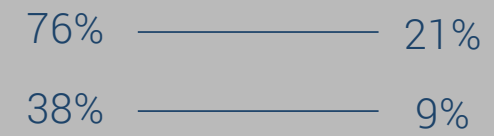

$12 \%$

$3 \%$

$9 \%$

$3 \%$

Primary risk drivers in direct operations and within the value chain

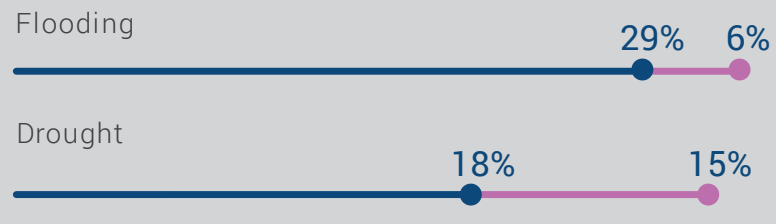

Increased water stress

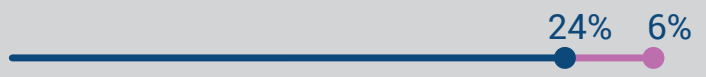

Increased water scarcity

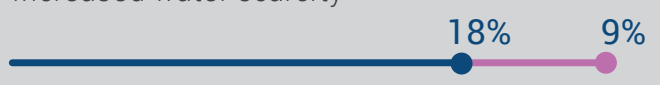

Declining water quality

$18 \%$

Higher water prices

$15 \% 3 \%$

Severe weather events

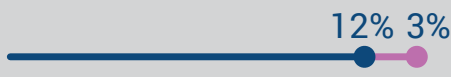

Inadequate infrastructure

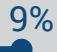

Increased stakeholder concern or negative stakeholder feedback $6 \% 3 \%$

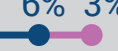

Primary potential impact of identified risks in direct operations and within value chain

Increased operating costs

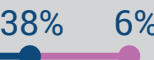

Reduction or disruption in production capacity

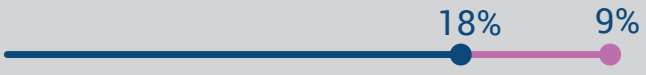

Reduced revenues from lower sales/output

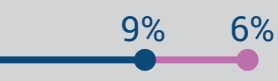

Disruption to sales

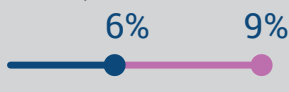

Brand damage

$9 \% 3 \%$

Supply chain disruption

$12 \%$

Closure of operations

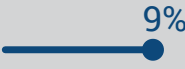

Increased production costs

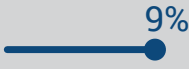

Changing revenue mix and sources

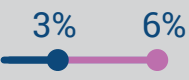

Reduced demand for products and services

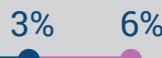

Fines, penalties or enforcement orders

$3 \% 3 \%$

Impact on company assets 


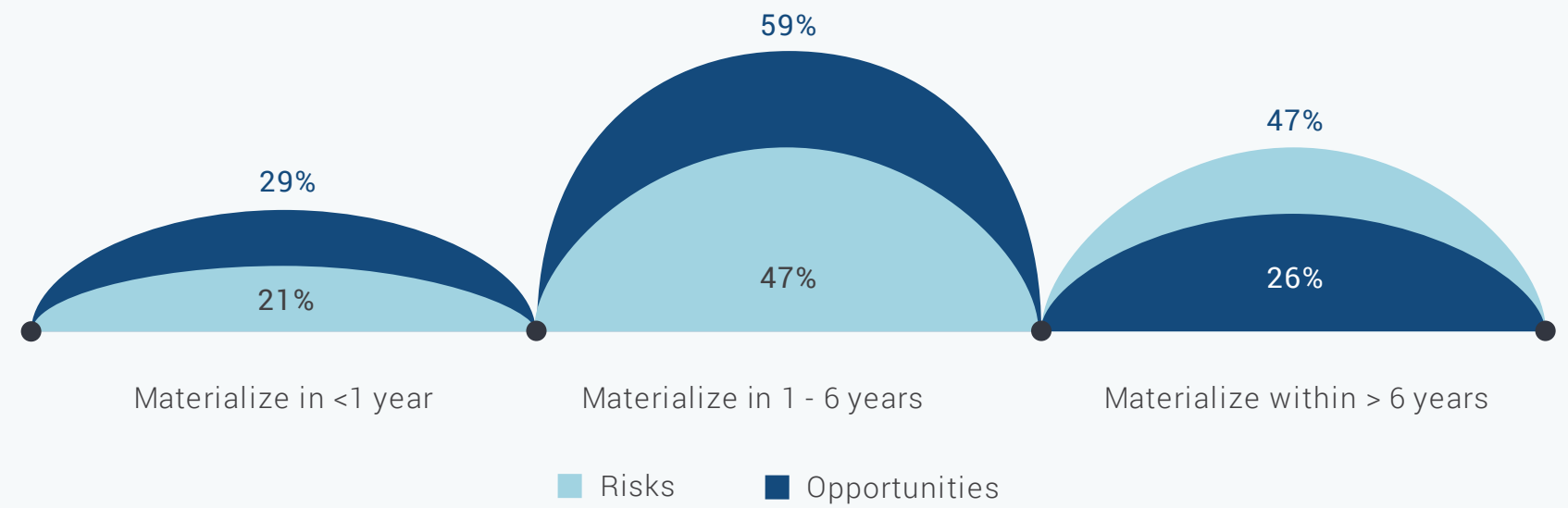

Primary water related opportunities currently being realized

\section{$41 \%$ Cost saving} $32 \%$ Improved water afficiency in

$24 \%$ Increased brand value

$97 \%$

have board level

oversight of water-related issues

$56 \%$

identified CEO with

responsibility for waterrelated issues on the board

\section{$79 \%$}

have a company-wide water policy

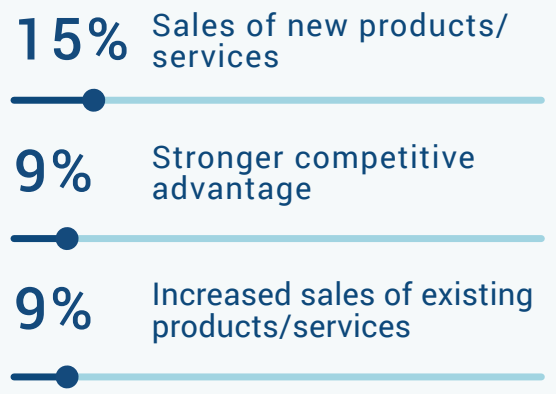

\section{Governance}

The strategic decisions taken by the CEO and the Board can truly transform a company's impact on water resources. By providing board members with the information and tools to plan for a transition to a watersecure world and by publicly monitoring their progress, water stewardship can become part of companies' business strategy. Almost all (97\%) companies report that they have board-level oversight of water-related issues within the organization. In more than half of the responding companies (56\%), CEO is the one with responsibility for waterrelated issues and $59 \%$ have incentives in place for C-Suite executives on water-related issues.

In Turkey, $79 \%$ of responding companies have company-wide water policy. A further $88 \%$ engage in activities that could either directly or indirectly influence public policy on water. $41 \%$ of companies include information about their response to waterrelated risks in their most recent mainstream financial report.
9\% Increased resilience to $9 \%$ impacts of climate change

$6 \%$ New R\&D opportunities $\longrightarrow$
Likewise climate change risks, in Eti Soda, the Board - the highest level of the company are responsible to manage, monitor and take action for the water-related issues and its impacts over the Board strategy discussions, portfolio review and investment decisions. With the assist of the Sustainability Committee, the Board is the decision maker on waterrelated issues, risks and opportunities. The Sustainability Committee works to identify potential risk before the company face. In order to enhance this work, the Board has decided to receive support from experts and academicians. The Sustainability Committee schedule its regular meetings with those climate change,

GHG emission, socio-economic biodiversity experts. 
$65 \%$

\section{use climate-related scenario analysis}

$18 \%$

\section{use an internal price on} water

As water cost is a part of Korda's OPEX and they also use this cost while deciding on the feasibility of water-related CAPEX, Kordsa always includes water price in budget planning. As Kordsa operates in very different geographies including Turkey, Indonesia, the United States, Thailand and Brazil, they take into account local water price while planning their budget. Therefore, they don't have a single figure. As the water scarcity is expected to increase in the future, they make sure they plan and initiate efficiency projects to ensure water security and prevent the OPEX increase likely to be caused by increasing water prices.

\section{\ Business Strategy}

Leading companies recognize that businessas-usual responses to business and water management are no longer sufficient to deal with the risks and opportunities they face. Integrating water into financial planning, long-term objectives and having strategies for achieving these are crucial steps on this journey. The purpose of this module is to collect information on how a company is adapting its long-term business model to secure a sustainable future, in terms of both its own resilience and securing water for all.

65 percent of responding companies in Turkey identified water-related outcomes from the organization's climate-related scenario analysis.

Only $18 \%$ of companies use an internal price on water, which is much lower than the companies that use an internal carbon price in Turkey (41\%).

Companies are also looking into medium and long-term strategies on water issues and have integrated the water aspects (strategy for achieving long-term objectives, long-term business objectives and financial planning) into their business plans. Looking at the longer term $85 \%$ of respondents in Turkey are integrating water-related issues into organization's long-term strategic business plan. A further $44 \%$ integrated those issues into strategic business plan for more than 10 years. While $74 \%$ of companies
$82 \%$

company-wide targets and goals in place to manage water risks

Migros uses the WRI Aqueduct Tool to assess water risk for facilities within operational control and for suppliers, which relies on two different climaterelated scenarios for projecting future changes to water supply, seasonal variability, demand, etc. Thanks to the tool, Migros gets information on what water risks and food security risks are, especially regarding agricultural products, by 2030 and 2040 . Water risks include risks such as water stress, drought risk, and seasonal variability. In this way, Migros has established a vital tracking mechanism for agricultural products that make up $77 \%$ of the sales in our stores. Migros indicated that this tracking mechanism is vital because by identifying which agricultural products have higher/much higher risk related to seasonal variability or any other water issue, it has an opportunity to engage with suppliers and plan diversification of suppliers for most risky products.

The categories of targets and goals that are monitored at the corporate level

\section{Targets}

$41 \%$ Water whithdrawals

$24 \%$ Water consumption

$15 \%$ Product water intensity

\begin{tabular}{ll}
$\longrightarrow 9 \%$ & Monitoring of water use \\
\hline $9 \%$ & Water pollution reduction \\
$\underset{9 \%}{6 \%}$ & $\begin{array}{l}\text { Water, Sanitation and Hygiene } \\
\text { (WAHS) services in the workplace }\end{array}$ \\
$\underset{6 \%}{6}$ & Water use efficiency \\
\hline & Water discharge \\
\hline
\end{tabular}

Goals

$18 \%$ Providing acces to safely

$18 \%$ managed Water, Sanitation and Hygiene (WASH) in workplace

$18 \%$ Engaging with customers to help them minimize product impacts

Engagement with public policy

$\mathbf{1 5 \%}$ makersto advance susutainable water managementand policies

$12 \%$ Promotion of sustainable agriculture practices

$12 \%$ Promotion of water data transparency

9\% Watershed remediationand habitat restoration,ecosystem preservation

9\% Engagement with suppliers to reduce the

$9 \%$ water-related impact of supplied products

$6 \%$ Improve wastewater quality beyond

6\% Improve wastewater quality 
Thanks to water efficiency projects realized in Arçelik's plants, in 2018 Arçelik reduced their average water withdrawal per product $48 \%$ (incl. Turkey, China, Romania, Russia, and South Africa) compared to 2012. In 2017, their 2020 water target was to reduce water withdrawal per product in production by $38 \%$. In 2018 , water withdrawal per product was reduced by $48 \%$ and the target for 2020 has been reached. Because of this, they have updated their 2020 water target to $52 \%$, and South Africa Plants were also included in the target.

\section{$79 \%$}

\section{have a company-wide water policy}

Since Yünsa operates in Ergene Basin which has both water quality and water quantity risks, Yünsa has targets for water withdrawals and water consumption. They aim to decrease their water intensity (m3 of water withdrawals per meter of produced fabric) by $40 \%$ from the year 2016 to 2020. have considered water-related issues in their financial planning, $82 \%$ have considered it in their long-term business objectives.

Companies must set and achieve ambitious targets to reduce impacts on water availability and quality. There is an increased commitment of companies in Turkey to manage and sustain water security. CDP defines a 'target' as a specific measurable output within a clear timeline, while a 'goal' aims to achieve a longer-term qualitative outcome or a specific change in behavior or circumstances. Targets are quantifiable objectives to manage water resources, and goals are qualitative aims leading towards improved water stewardship. Most of the companies (82\%) have set company-wide targets and goals in place to better manage water risks. $56 \%$ of responding companies achieved more than half of their water targets.

In Turkey, $85 \%$ of responding companies are monitored targets and goals at the corporate level. Water withdrawals are the most common category of targets that are monitored (41\%). The most common category of water-related goals monitored at the corporate level are engagement with customers to help them minimize product impacts (18\%) and providing access to safely managed Water, Sanitation and Hygiene (WASH) in workplace (18\%).

The percentage of respondents that provide a quantitative metric for water targets is $82 \%$. A further $65 \%$ provide a description of water goals. Reduced environmental impacts (50\%) is the primary motivation behind targets and the primary motivation behind the goals is water stewardship (32\%)
In middle of the 2018 our new factory, tumbler dryer machine, has been run

This change lead to an increase in water consumption. In this manner, a new base year and target have been

set. Vestel Beyaz Eşya set the goal

of reducing water usage amount by

$\% 15$ per water sourced from municipal

supply compared to 2019 until 2030 to

manage and reduce water consumption in domestic and overseas sites.

Motivations behind the water related targets and goals

\section{Targets}

$50 \%$ Reduced enviromental impacts

$15 \%$ Climate change adaptation and $15 \%$ mitigation strategies

$15 \%$ Risk mitigation

$12 \%$ Water stewardship

$12 \%$ Recommended sector best practice
Goals

$32 \%$ Water Stewardship

$26 \%$ Reduced enviromental impacts

$24 \%$ shared value

$15 \%$ Commitment to the UN Sustainable

$12 \%$ Corporate social responsibility
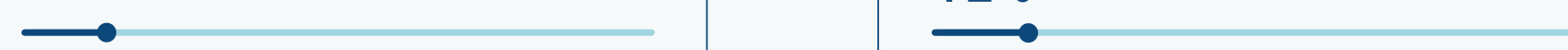


\section{SCORE DISTRIBUTION}

\section{TURKEY 2020}

VDP Scoring: A growing environmental awareness among the business in 2020

Globally 313 companies named on CDP's prestigious 'A List' this year for environmental transparency and action, a 45\% increase from 2019.

The A List showcases the companies leading on environmental transparency and action, based on their annual disclosure through CDP's climate change, forests and water security questionnaires. This year has seen a major increase in the number of companies achieving an A score, with increases across all three themes that CDP assesses. Along with the high levels of disclosure, this shows growing environmental awareness among the business world in 2020 despite the unprecedented challenges posed by Covid-19.

In Turkey, Garanti BBVA made the CDP Climate $A$ list and Tekfen Holding achieved a 'double A' score for Climate and Water, being one of the 63 companies in the World.

8 companies ( 5 in 2019) achieved a score of 'A-' across Climate and another 8 (2 in 2019) across Water are recognized as pioneers of business in Turkey for environmental reporting.

Management and leadership levels (A \& B scores) require demonstration of good or leading environmental performance as well as transparency. In 2020, the number of A and $B$ band scored companies in Turkey across Climate is 36 and across water is 29 in total. That number is steadily increasing year by year.

\section{CDP Supplier Engagement Rating (SER)}

Companies' average upstream emissions are around 11.4 times greater than their direct operations. Therefore, companies have much greater potential to reduce global emissions by influencing their supply chains. CDP's annual Supplier Engagement Rating provides a rating for how effectively companies are engaging their suppliers on climate change. CDP assesses performance on supplier engagement using a company's response to selected questions on governance, targets, value chain (scope 3 ) emissions and supplier engagement strategies in the CDP Climate Change questionnaire. By engaging their suppliers on climate change companies are playing a crucial role in the transition towards the net-zero sustainable economy. We have 3 companies in Turkey achieved a score of A: Arçelik, Brisa and Garanti BBVA. A further 11 companies from various sectors also receive ' $A-$ '. The highest-rated companies are celebrated in the Supplier Engagement Rating Leaderboard: https://www.cdp.net/en/ research/global-reports/transparency-totransformation

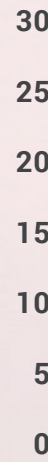

25
15
10
5
0
2

0

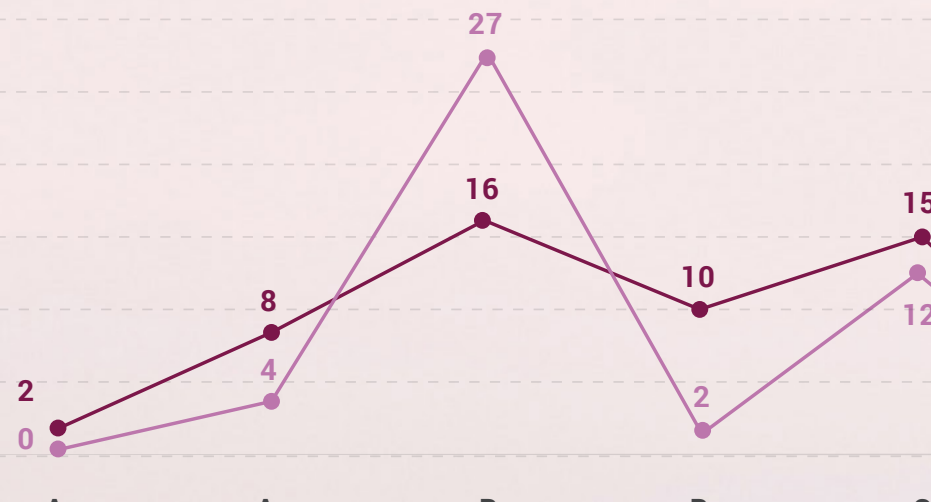

A

A-

B

2019 Climate Change

2020 Climate Change
30

5

0

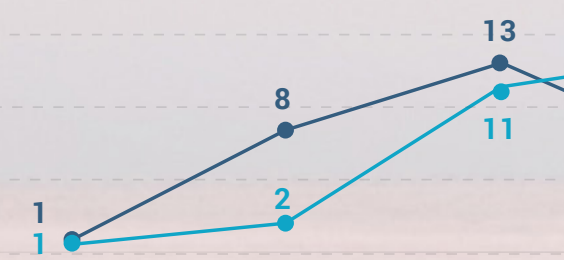

A
A-

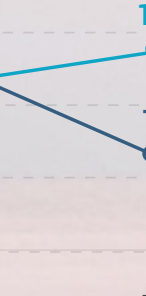

B-

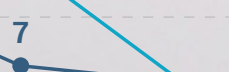

C
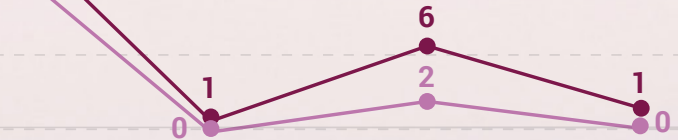

C-
D- 


\section{CDP TURKEY LEADERS}

TURKEY 2020

T.GARANTI BANKASI A.Ş.

TEKFEN HOLDING A.Ş.

CDP GLOBAL WATER A LIST

TEKFEN HOLDING A.Ş.

Infrastructure
Services

A

Infrastructure

\section{CDP TURKEY CLIMATE CHANGE LEADERS}

ALBARAKA TÜRK KATILIM BANKASI A.Ş.

ARÇELIK A.Ş.

ASELSAN ELEKTRONIK SANAYI VE TICARET A.Ş.

BRISA BRIDGESTONE SABANCI LASTIK SAN. VE TIC. A.Ş.

KORDSA TEKNIK TEKSTIL A.Ş.

PEGASUS HAVA TAŞIMACILIĞI A.Ş.

T.iş BANKASI A.Ş.

TÜRKIYE KALKINMA VE YATIRIM BANKASI A.Ş.
Services

A-

Manufacturing

A-

Manufacturing

A-

Manufacturing

A-

Manufacturing

A-

Transportation services

Services

Services

\section{CDP TURKEY WATER LEADERS}

AKSA AKRILIK KIMYA SANAYIi A.Ş.

Materials

A-

ARÇELIK A.Ş.

Manufacturing

BRISA BRIDGESTONE SABANCI LASTIK SAN. VE TIC. A.Ş.

Manufacturing

A-

ETI SODA A.Ş.

Materials

A-

KORDSA TEKNIK TEKSTIL A.Ş.

Manufacturing

A-

Retail

A-

Food, beverage \& agriculture

A-

Services

A-

\section{CDP SUPPLIER ENGAGEMENT RATING GLOBAL LEADERS}

ARÇELIK A.Ş.

BRISA BRIDGESTONE SABANCI LASTIK SAN. VE TIC. A.Ş.

T.GARANTI BANKASI A.S.
Manufacturing

A

Manufacturing

A

Services 


\section{CDP'S OTHER CAMPAIGNS AND PROGRAMS}

\section{TURKEY 2020}

\section{What is TCFD?}

The Task Force on Climate-Related

Financial Disclosures (TCFD) is an

organization that was established in

December of 2015 with the goal of

developing a set of voluntary climate-

related financial risk disclosures that

can be adopted by companies so that

those companies can inform investors

and other members of the public about

the risks they face related to climate

change. The organization was formed

by the Financial Stability Board (FSB)

as a means of coordinating disclosures

among companies impacted by climate

change. In 2017, the TCFD released

climate-related financial disclosure

recommendations designed to help

companies provide better information to

support informed capital allocation. The

recommendations are structured around

four thematic areas that represent core

elements of how organizations operate:

governance, strategy, risk management

and metrics and targets.

\section{What is Science-Based Targets}

Science-based targets provide a clearly defined pathway for companies to

reduce greenhouse gas $(\mathrm{GHG})$ emissions,

helping prevent the worst impacts

of climate change and future-proof

business growth. Targets are considered

'science-based' if they are in line with

what the latest climate science deems

necessary to meet the goals of the Paris

Agreement - limiting global warming

to well-below $2^{\circ} \mathrm{C}$ above pre-industrial

levels and pursuing efforts to limit

warming to $1.5^{\circ} \mathrm{C}$.

\section{CDP disclosure and the TCFD recommendations}

With an amendment made in 2018, CDP

questions were aligned with the TCFD

Framework. CDP added 25 TCFD-aligned

questions contained within the Governance,

Risks \& Opportunities, Strategy, Targets, and

Emissions modules. Therefore, companies

responding to CDP can also make a

reporting that largely complies with the

recommendations of TCFD and can reduce

their reporting burden.

In 2019, 2,508 companies from around the world - worth over US\$ 41 trillion in market capitalization - responded to CDP's climate change information request, which was sent to them by CDP on behalf of their investors. The overviews below examine to what extent these companies are disclosing in line with the recommendations of the Task Force on Climate-related Financial Disclosure (TCFD).

Globally, CDP finds that a large number of companies are already disclosing climate-related information through CDP in a way that is aligned with the TCFD recommendations:

- $35 \%$ of companies provide information on all TCFD recommended disclosures through CDP.

- A further $34 \%$ responded to the majority of the TCFD recommended disclosures.

- $69 \%$ (over 1700 companies) are thus disclosing information on at least $80 \%$ of the recommended disclosures.

\section{\ CDP and Science-Based Targets}

The Science Based Targets Initiative (SBTi) is a partnership between CDP, the United Nations Global Compact (UNGC), World Resources Institute (WRI), and the World Wide Fund for Nature (WWF). The SBTi call to action is one of the We Mean Business Coalition commitments. SBTi:

- defines and promotes best practice in emissions reductions and net-zero targets in line with climate science.

- provides technical assistance and expert resources to companies who set sciencebased targets in line with the latest climate science.

- brings together a team of experts to provide companies with independent assessment and validation of targets.

- is the lead partner of the Business Ambition for $1.5^{\circ} \mathrm{C}$ campaign - an urgent call to action from a global coalition of UN agencies, business, and industry leaders, mobilizing companies to set net-zero science-based targets in line with a $1.5^{\circ} \mathrm{C}$ future.

As of 2019, companies who signed up to the SBTi had operational emissions totaling over 750 million tonnes of $\mathrm{CO} 2 \mathrm{e}$ - more than the annual emissions of France and Spain put together. Their combined market capitalization was over US\$10.8 trillion.

Among them are pioneers from some of the highest-emitting sectors, such as cement, power generation, and steel.

Science-based target setting is already becoming part of the yearly reporting practice of companies and the data infrastructure for institutional investors through incorporation in the CDP questionnaire and scoring.

\section{SBTi Status of Companies in Turkey*}

The companies that have already set a

Science- Based Target that well-below $2^{\circ} \mathrm{C}$

The companies committed to set a Science-Based Target
Company name

ARÇELIKK A.Ş.

KAYSERI ULAŞIM A.Ş.

ABDI İBRAHIM ILAÇ SANAYI VE TICARET A.Ş.

ALBARAKA TÜRK KATILIM BANKASI A.Ş.

T.GARANTI BANKASI A.Ş.

T.SINAI KALKINMA BANKASI A.Ş.

TÜRKIYE IŞ BANKASI A.Ş.

TÜRKIYE VAKIFLAR BANKASI T.A.O. 


\section{- CDP Commit to Action Campaign and We Mean Business Coalition}

What are the We Mean Business

Coalition and the Commit to Action campaign?

We Mean Business is a global non-profit coalition that brings together seven international nonprofit organizations including CDP. The mission is to ensure that the world economy is on track to avoid dangerous climate change while delivering sustainable growth and prosperity for all.

CDP's Commit to Action campaign works with the world's most influential companies to encourage them to sign up to climate leadership commitments supported by the We Mean Business Coalition which mobilizes businesses to set ambitious targets and equipping them to seize the opportunities of the zero-carbon transition and encourage governments to create the enabling policies that support companies to deliver bold climate action at scale.

\section{CDP Cities Program}

CDP provides the global platform for cities to measure, manage and disclose their environmental data. CDP works with over 900 cities measuring and disclosing environmental data each year to manage emissions, build resilience, protect themselves from climate impacts and create better places for people to live and work. The main benefits of reporting through CDP include:

- Gain insight and feedback on your city's climate action and response through CDP scoring.

- Compile all your environmental data in one place.

- Track your city's sustainability and climate efforts annually.

- Access data from $900+$ cities, $120+$ states and regions, and 9,500+ companies.

- Enter the ecosystem of the world's best city initiatives and programs. Participate in the Global Covenant of Mayors, as well as other initiatives offered by our partners ICLEI, C40 and WWF.
- Profile your low carbon mitigation projects with CDP's investor network representing $\$ 106$ trillion in assets.

In 2019, CDP partnered with ICLEI Local Governments for Sustainability to present one unified platform for city climate reporting, streamlining the process of reporting and ensuring simplicity and standardization for reporting cities.

In 2020, 11 municipalities from Turkey disclosed their environmental data through CDP:

- Adana Metropolitan Municipality

- Balıkesir Metropolitan Municipality

- Denizli Metropolitan Municipality

- Eskişehir Metropolitan Municipality

- Gaziantep Metropolitan Municipality

- Istanbul Metropolitan Municipality

- Kadıköy Municipality (Istanbul)

- Mezitli Municipality (Mersin)

- Nilüfer Municipality (Bursa)

- Seferihisar Municipality (Izmir)

- Village of Kadıovacık (Izmir)
CDP Turkey Respondents that Committed to Action*
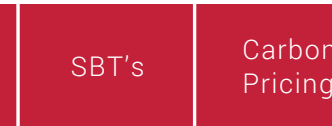

Responsible Climate policy
Report Climate Change Information

ABDI IBRAHIM ILAÇ SANAYI VE TICARET A.Ş.

AKÇANSA ÇIMENTO SANAYI VE TICARET A.Ş.

8 8

8า

ARÇELIK A.Ş.

率

ALBARAKA TURK KATILIM BANKASI A.Ş.

ÇIMSA ÇIMENTO SANAYIi VE TICARET A.Ş.

KAYSERI ULAŞIM A.Ş.

ŞEKERBANK T.A.Ş.

T.GARANTI BANKASI A.Ş.

T.SINAI KALKINMA BANKASI A.Ş.

TÜRKIYE IŞ BANKASI A.Ş.

TÜRKIYE VAKIFLAR BANKASI T.A.O.

*(As of 10/03/2021) 


\section{CDP TURKEY CLIMATE CHANGE SAMPLE (BIST-100)}

COMPANY - REQUESTED

A.V.O.D. KURUTULMUŞ GIDA VE TARIM ÜRÜNLERI A.Ş.

ADESE ALIŞVERIŞ MERKEZLERI TICARET A.Ş.

AFYON ÇIMENTO SANAYI T.A.S.

AG ANADOLU GRUBU HOLDING A.Ş.

AKBANK T.A.S

AKSA AKRILIK KIMYA SANAYII A.Ş.

AKSA ENERJI ÜRETIM A.Ş.

ALARKO GAYRIMENKUL YATIRIM A.Ş.

ALARKO HOLDING A.Ş.

ALBARAKA TÜRK KATILIM BANKASI A.Ş.

ANADOLU CAM SANAYII A.Ş.

ANADOLU EFES BIRACILIK VE MALT SANAYIi A.Ş.

ARÇELIK A.Ş.

ASELSAN ELEKTRONIK SANAYI VE TICARET A.S.

BERA HOLDING A.Ş.

BEŞIKTAŞ FUTBOL YATIRIMLARI SANAYI VE TICARET A.Ş.

BIM BIRLEŞiK MAĞAZALAR A.Ş.

COCA-COLA IÇECEK A.Ş.

ÇELEBI HAVA SERVISI A.Ş.

ÇEMAŞ DÖKÜM SANAYI A.Ş.

ÇEMTAŞ ÇELIK MAKINA SANAYI VE TICARET A.Ş.

DOĞAN ŞIRKETLER GRUBU HOLDING A.Ş.

DOĞTAŞ KELEBEK MOBILYA SANAYI VE TICARET A.Ş.

EGE ENDÜSTRI TICARET A.Ş.

EIS ECZACIBAŞI ILAÇ, SINAI VE FINANSAL YATIRIMLAR SANAYI VE TICARET A.Ş.

EMLAK KONUT GAYRIMENKUL YATIRIM ORTAKLIĞI A.Ş.

ENERJISA ENERJI A.Ş.

ENKA INŞAAT VE SANAYI A.Ş.

EREĞLI DEMIR VE ÇELIK FABRIKALARI T.A.Ş.

FENERBAHÇE SPORTIF HIZMETLER SANAYI VE TICARET A.Ş

FORD OTOMOTIV SANAYI A.Ş,

GALATASARAY SPORTIF SINAI VE YATIRIMLAR A.S.

GENTAŞ GENEL METAL SANAYI VE TICARET A.Ş.

GERSAN ELEKTRIK TICARET VE SANAYI A.S.

GÖLTAŞ GÖLLER BÖLGESI ÇIMENTO SAN. VE TIC.A.Ş.

GÖZDE GIRIŞiM SERMAYESI YATIRIM ORTAKLIĞI A.Ş.

GSD HOLDING A.S.

GÜBRE FABRIKALARI T.A.Ş.

HEKTAŞ TICARET T.A.Ş.

HÜRRIYET GAZETECILIK VE MATBAACILIK A.Ş.

ICBC TURKEY BANK A.S.

IŞIKLAR ENERJI VE YAPI HOLDING A.Ş.
PRIMARY QUESTIONNAIRE

\begin{tabular}{|l|}
\hline Food, beverage \& tobacco \\
\hline General \\
\hline Cement \\
\hline Food, beverage \& tobacco \\
\hline Financial services \\
\hline Chemicals \\
\hline
\end{tabular}

Chemicals

Electric utilities

Real estate

Construction

Financial services

General

Food, beverage \& tobacco

General

Capital goods

Paper \& forestry

General

General

Food, beverage \& tobacco

General

Steel

Steel

Oil \& gas

General

General

General

General

Electric utilities

Electric utilities

Steel

General

Transport OEMS

General

General

General

Cement

Financial services

Financial services

Chemicals

Chemicals

General

Financial services

General

\begin{tabular}{c|c} 
F & NS \\
\hline F & NS
\end{tabular}

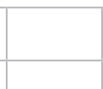

\begin{tabular}{|c|l|}
\hline & \\
\hline & \\
\hline Yes & Intensity target \\
\hline Yes & Absolute \& intensity targets \\
\hline & \\
\hline Yes & Absolute \& intensity targets \\
\hline Yes & Intensity target \\
\hline Yes & Absolute \& intensity targets \\
\hline
\end{tabular}

Yes Intensity target 
RESPONSE STATUS

CLIMATE CHANGE / TURKEY 2020

\section{CDP TURKEY CLIMATE CHANGE SAMPLE (BIST-100)}

COMPANY - REQUESTED

PRIMARY QUESTIONNAIRE

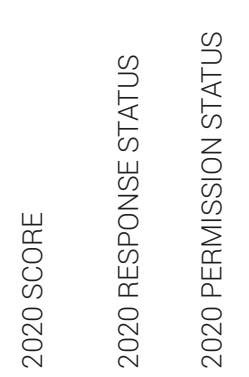

IHLAS GAYRIMENKUL PROJE GELIŞTiRME VE TICARET A.Ş.

IHLAS HOLDING A.S.

INDEKS BiLGiSAYAR SISTEMLERI MÜHENDISLIK SANAYI VE TiCARET A.Ş,

General

IPEK DOĞAL ENERJI KAYNAKLARI ARAŞTIRMA VE ÜRETIM A.Ş.

Construction

General

ISKENDERUN DEMIR VE ÇELIK A.Ş

Iş FinANSAL KiRALAMA A.Ş.

IŞ GAYRIMENKUL YATIRIM ORTAKLIĞI A.Ş.

ITTIFAK HOLDING A.S.

KARDEMIR KARABÜK DEMIR ÇELIK SANAYI VE TICARET A.Ş.

KARSAN OTOMOTIV SANAYIII VE TICARET A.S

KEREVITAŞ GIDA SANAYI VE TICARET A.Ş.

KOÇ HOLDING A.S

KONYA ÇIMENTO SANAYIII A.Ş.

KORDSA TEKNIK TEKSTIL A.Ş.

KOZA ALTIN IŞLETMELERI A.S.

KOZA ANADOLU METAL MADENCILIK IŞLETMELERI A.Ş.

MAVI GIYYM SANAYI VE TICARET A.Ș.

METRO TICARI VE MALI YATIRIMLAR HOLDING A.S

MIGROS TICARET A.S.

MLP SAĞLIK HIZMETLERI A.Ș.

NET HOLDING A.S.

NETAŞ TELEKOMÜNIKASYON A.S.

ODAŞ ELEKTRIK ÜRETIM SANAYI TICARET A.Ş

OTOKAR OTOMOTIV VE SAVUNMA SANAYI A.Ş.

ÖZDERICI GAYRIMENKUL YATIRIM ORTAKLLĞI A.S.

PARK ELEKTRIK ÜRETIM MADENCILIK SANAYI VE TICARET A.Ş.

PARSAN MAKINA PARÇALARI SANAYI A.S.

PEGASUS HAVA TAŞIMACILIĞI A.Ş.

PETKIM PETROKIMYA HOLDING A.Ş.

POLISAN HOLDING A.Ş.

SABANCI HOLDING A.Ş.

SASA POLYESTER SANAYI A.Ş.

SODA SANAYI A.Ş.

ŞEKERBANK T.A.S.

ŞOK MARKETLER TICARET A.Ş.

T.GARANTI BANKASI A.S.

T.IŞ BANKASI A.Ş.

T.SINAI KALKINMA BANKASI A.Ş.

T.ŞiŞE VE CAM FABRIKALARI A.S

TAV HAVA LIMANLARI HOLDING A.Ş.

TEKFEN HOLDING A.Ş.

TOFAŞ TÜRK OTOMOBIL FABRIKASI A.Ş.

TRAKYA CAM SANAYII A.Ş.

Oil \& gas

Steel

Financial services

Real estate

Financial services

Steel

Transport OEMS

Food, beverage \& tobacco

Oil \& gas

Cement

General

Metals \& mining

Metals \& mining

General

Transport services

General

General

Financial services

General

Electric utilities

Transport OEMS

General

Electric utilities

Transport OEMS

Transport services

Chemicals

Chemicals

General

Chemicals

Chemicals

Financial services

General

Financial services

Financial services

Financial services

General

General

Chemicals

Transport OEMS

General

\begin{tabular}{|c|c|}
\hline F & NS \\
\hline F & NS \\
\hline
\end{tabular}




\section{CDP TURKEY CLIMATE CHANGE SAMPLE (BIST-100)}

COMPANY - REQUESTED

TUKAŞ GIDA SANAYI VE TICARET A.Ş,

TURKCELL ILETiŞiM HIZMMETLERI A.Ș

TÜMOSAN MOTOR VE TRAKTÖR SANAYI A.S.

TÜPRAS-TÜRKIYY PETROL RAFINERILERI AS

TÜRK HAVA YOLLARI A.O.

TÜRK TELEKOMÜNIKASYON A.S.

TÜRK TRAKTÖR VE ZIRAAT MAKINELERI A.Ş.

TÜRKIYE HALK BANKASI A.S

TÜRKIYE VAKIFLAR BANKASI T.A.O.

ÜLKER BISKÜVI SANAYI A.Ş.

VERUSA HOLDING A.Ş.

VESTEL ELEKTRONIK SANAYI VE TICARET A.S.

YAPI VE KREDI BANKASI A.Ş.

YATAŞ YATAK VE YORGAN SANAYI VE TICARET A.S.

ZORLU ENERJI ELEKTRIK ÜRETIM A.Ş.

OTHER RESPONDING COMPANIES

\begin{tabular}{|c|c|c|c|c|c|c|}
\hline ABDI IBRAHIM ILAÇ SANAYI VE TICARET A.Ş. & General & B- & S & NP & Yes & \\
\hline AKÇANSA ÇIMENTO SANAYI VE TICARET A.Ş. & Cement & B- & S & $P$ & Yes & Intensity target \\
\hline AKENERJI ELEKTRIK ÜRETIM A.Ş. & Electric utilities & B- & s & $\mathrm{P}$ & Yes & Intensity target \\
\hline AYDEM YENILENEBILIR ENERJI A.Ş. & Electric utilities & D & S & $P$ & Yes & \\
\hline BRISA BRIDGESTONE SABANCI LASTIK SAN. VE TIC. A.Ş. & General & A- & s & $P$ & Yes & Absolute \& intensity targets \\
\hline CARREFOURSA CARREFOUR SABANCI TICARET MERKEZI A.Ş. & General & D & S & NP & No & \\
\hline ÇiMSA ÇIMENTO SANAYIi VE TICARET A.Ş. & Cement & B- & s & $\mathrm{P}$ & Yes & Absolute \& intensity targets \\
\hline DURAN DOĞAN BASIM VE AMBALAJ A.Ş & General & B- & s & NP & Yes & Absolute \& intensity targets \\
\hline EKOTEN TEKSTIL SANAYI VE TICARET A.Ş. & General & c & S & $P$ & Yes & Absolute \& intensity targets \\
\hline ETI SODA A.Ş. & Metals \& mining & B & S & $\mathrm{P}$ & Yes & Absolute \& intensity targets \\
\hline GAZDAŞ GAZIANTEP DOĞAL DAĞITIM A.Ş. & General & C & S & $P$ & Yes & \\
\hline GENEL ENERGY PLC & Oil \& gas & D & s & $P$ & No & Absolute target \\
\hline İHLAS EV ALETLERI IMALAT SANAYI VE TICARET A.Ş. & General & D & s & NP & No & \\
\hline KAYSERI ULAŞIM A.Ş. & Transport services & B & s & $P$ & Yes & Intensity target \\
\hline OSMANGAZI ELEKTRIK DAĞITIM A.Ş. & Electric utilities & D & S & $P$ & Yes & \\
\hline PINAR ENTEGRE ET VE UN SANAYIi A.Ş. & Food, beverage \& tobacco & B- & S & NP & Yes & Intensity target \\
\hline PINAR SÜT MAMULLERI SANAYii A.Ş. & Food, beverage \& tobacco & D & s & NP & Yes & Intensity target \\
\hline SUN TEKSTIL SANAYI VE TICARET A.Ş. & General & C & SA & & & \\
\hline TÜRKIYE KALKINMA VE YATIRIM BANKASI A.Ş. & Financial services & A- & S & $P$ & Yes & Absolute \& intensity targets \\
\hline VESTEL BEYAZ EŞYA SANAYI VE TICARET A.Ş. & General & C & s & $P$ & Yes & Intensity target \\
\hline YÜNSA YÜNLÜ SANAYI VE TICARET A.Ş. & General & B- & s & $\mathrm{P}$ & Yes & Intensity target \\
\hline ZORLU DOĞAL ELEKTRIK ÜRETIMI A.Ş. & Electric utilities & B & SA & & & \\
\hline
\end{tabular}

Key to Response Status Tables

(S) Submitted (NS) Not submitted (No response or Declined to Participate) (SA) See Another (Company is either a subsidiary or the parent company is already responding to CDP) (P) Public (NP) Non-public (N/A) Not scored because company responded the short version of questionnaire (F) Failure to provide sufficient information to CDP to be evaluated for this purpose.

\begin{tabular}{|l|c|c|c|c|l|}
\hline Food, beverage \& tobacco & F & NS & & & \\
\hline General & B & S & P & Yes & Absolute target \\
\hline General & F & NS & & & \\
\hline Oil \& gas & F & NS & & & \\
\hline Transport services & F & NS & & & \\
\hline General & B- & S & NP & Yes & \\
\hline Capital goods & F & NS & & & \\
\hline Financial services & B & S & P & Yes & Intensity target \\
\hline Financial services & B & S & P & Yes & Absolute \& intensity targets \\
\hline Food, beverage \& tobacco & C & S & NP & Yes & Intensity target \\
\hline General & F & NS & & & \\
\hline General & C & S & P & Yes & Absolute target \\
\hline Financial services & B & S & P & Yes & Absolute target \\
\hline General & F & NS & & & \\
\hline Electric utilities & B & S & P & Yes & Absolute \& intensity targets \\
\hline
\end{tabular}

Electric utilities

Absolute \& intensity targets 
RESPONSE STATUS

WATER SECURITY / TURKEY 2020

CDP TURKEY WATER SAMPLE (BIST-100)

COMPANY - REQUESTED

PRIMARY QUESTIONNAIRE

AFYON ÇIMENTO SANAYI T.A.S

Cement

AKÇANSA ÇIMENTO SANAYI VE TICARET A.S.

AKENERJI ELEKTRIK ÜRETIM A.Ş.

Cement

AKSA AKRILIKK KIMYA SANAYIII A.Ş.

Electric utilities

AKSA ENERJI ÜRETIM A.Ş.

ANADOLU CAM SANAYIII A.S.

ANADOLU EFES BIRACILIK VE MALT SANAYII A.S

ARÇELLKK.SS.

ASELSAN ELEKTRONIK SANAYI VE TICARET A.Ş

AYGAZA.S.

BiM BIRLEȘiK MAĞAZALAR A.S

Chemicals

Electric utilities

General

Food, beverage \& tobacco

General

Capital goods

General

BORUSAN MANNESMANN BORU SANAYI VE TICARET A.Ş.

BRISA BRIDGESTONE SABANCI LASTIK SAN. VE TIC. A.Ş

CARREFOURSA CARREFOUR SABANCI TICARET MERKEZI A.Ş.

ÇIMSA ÇIMENTO SANAYIi VE TICARET A.Ş.

COCA-COLA IÇECEKA.Ş,

DOĞAN ŞIRKETLER GRUBU HOLDING A.Ş.

EIS ECZACIBAŞ I ILAÇ, SINAI VE FINANSAL YATIRIMLAR SANAYI VE TICARET A.S

ENERJISA ENERJI A.S.

ENKA INŞAAT VE SANAYI A.Ș

EREĞLI DEMIR VE ÇELIK FABRIKALARI T.A.Ş.

FORD OTOMOTIV SANAYI A.Ş.

GÜBRE FABRIKALARI T.A.S.

ISKENDERUN DEMIR VE ÇELIKA.Ş

IPEK DOĞAL ENERJI KAYNAKLARI ARAŞTIRMA VE ÜRETIM A.Ş.

General

Metals \& mining

General

General

Cement

Food, beverage \& tobacco

Oil \& gas

General

Electric utilities

Electric utilities

Steel

Transport OEMS

Chemicals

Oil \& gas

Steel

KARDEMIR KARABÜK DEMIR ÇELIK SANAYY VE TiCARET A.S

KOÇ HOLDING A.Ş,

Steel

KORDSA TEKNIK TEKSTIL A.Ş

KOZA ALTIN IŞLETMELERI A.Ş

KOZA ANADOLU METAL MADENCILIK IŞLETMELERI A.Ş.

MigRoS TiCARET A.S

NET HOLDING A.S

OTOKAR OTOMOTIV VE SAVUNMA SANAYI A.Ş

PETKIM PETROKIMYA HOLDING A.S.

POLISAN HOLDING A.S.

SASA POLYESTER SANAYI A.S.

SODA SANAYI A.S.

ŞOK MARKETLER TICARET A.Ş.

T.ŞSŞE VE CAM FABRIKALARI A.S

TEKFEN HOLDING A.Ş,

TOFAŞ TÜRK OTOMOBiL FABRIKASI A.Ș

Oil \& gas

General

Metals \& mining

Metals \& mining

General

Financial services

Transport OEMS

Chemicals

Chemicals

Chemicals

Chemicals

General

General

Chemicals

Transport OEMS

\begin{tabular}{|c|c|c|c|c|}
\hline B & SA & NP & Yes & \\
\hline B- & s & P & Yes & Higher \\
\hline B- & s & P & Yes & Higher \\
\hline$A^{-}$ & s & NP & Yes & About the same \\
\hline $\mathrm{F}$ & NS & & & \\
\hline $\mathrm{F}$ & NS & & & \\
\hline $\mathrm{F}$ & NS & & & \\
\hline$A^{-}$ & s & P & Yes & Lower \\
\hline $\mathrm{F}$ & NS & & & \\
\hline $\mathrm{F}$ & NS & & & \\
\hline $\mathrm{F}$ & NS & & & \\
\hline $\mathrm{F}$ & NS & & & \\
\hline$A^{-}$ & s & P & Yes & Much higher \\
\hline c & s & P & No & Lower \\
\hline B & $s$ & P & Yes & Much higher \\
\hline B & s & P & Yes & Higher \\
\hline $\mathrm{F}$ & NS & & & \\
\hline $\mathrm{F}$ & NS & & & \\
\hline $\mathrm{N} / \mathrm{A}$ & s & P & No & \\
\hline B & s & P & Yes & \\
\hline $\mathrm{F}$ & NS & & & \\
\hline B & $s$ & P & Yes & Lower \\
\hline $\mathrm{F}$ & NS & & & \\
\hline $\mathrm{F}$ & NS & & & \\
\hline $\mathrm{F}$ & NS & & & \\
\hline $\mathrm{F}$ & NS & & & \\
\hline $\mathrm{F}$ & NS & & & \\
\hline A- & s & P & Yes & About the same \\
\hline $\mathrm{F}$ & NS & & & \\
\hline $\mathrm{F}$ & NS & & & \\
\hline$A-$ & s & P & Yes & \\
\hline $\mathrm{F}$ & NS & & & \\
\hline $\mathrm{F}$ & NS & & & \\
\hline $\mathrm{F}$ & NS & & & \\
\hline c & s & NP & Yes & Lower \\
\hline $\mathrm{F}$ & NS & & & \\
\hline $\mathrm{F}$ & NS & & & \\
\hline $\mathrm{F}$ & NS & & & \\
\hline $\mathrm{F}$ & NS & & & \\
\hline A & s & P & Yes & Much higher \\
\hline B & S & $P$ & Yes & Lower \\
\hline
\end{tabular}


RESPONSE STATUS

WATER SECURITY / TURKEY 2020

CDP TURKEY WATER SAMPLE (BIST-100)

COMPANY - REQUESTED

PRIMARY QUESTIONNAIRE

\begin{tabular}{|c|c|c|c|c|c|c|}
\hline TRAKYA CAM SANAYIi A.Ş. & General & $\mathrm{F}$ & NS & & & \\
\hline TÜMOSAN MOTOR VE TRAKTÖR SANAYI A.Ș. & General & $\mathrm{F}$ & NS & & & \\
\hline TÜPRAŞ-TÜRKIYE PETROL RAFINERILERI A.Ş. & Oil \& gas & $\mathrm{F}$ & NS & & & \\
\hline TÜRK TRAKTÖR VE ZIRAAT MAKINELERI A.Ş. & Capital goods & $\mathrm{F}$ & NS & & & \\
\hline TÜRK TUBORG BIRA VE MALT SANAYIII A.Ş. & Food, beverage \& tobacco & $\mathrm{F}$ & NS & & & \\
\hline ÜLKER BISKÜVI SANAYI A.Ş. & Food, beverage \& tobacco & c & $\mathrm{s}$ & NP & Yes & About the same \\
\hline VESTEL BEYAZ EŞYA SANAYY VE TICARET A.Ş. & General & B- & $\mathrm{s}$ & $\mathrm{P}$ & Yes & Higher \\
\hline VESTEL ELEKTRONIK SANAYI VE TiCARET A.Ş. & General & c & s & $\mathrm{P}$ & Yes & Lower \\
\hline ZORLU ENERJII ELEKTRIK ÜRETIM A.Ş. & Electric utilities & B & $\mathrm{s}$ & $\mathrm{P}$ & Yes & Much higher \\
\hline
\end{tabular}

OTHER RESPONDING COMPANIES

\begin{tabular}{|c|c|c|c|c|c|c|}
\hline ABDi IBRAHIM ILAÇ SANAYI VE TICARET A.Ş. & General & B- & S & NP & Yes & Higher \\
\hline ALBARAKA TÜRK KATILIM BANKASI A.Ş. & Financial services & B- & s & P & Yes & About the same \\
\hline AYDEM YENILENEBILIR ENERJI A.Ş. & Electric utilities & c & $\mathrm{s}$ & $\mathrm{P}$ & Yes & \\
\hline DURAN DOĞAN BASIM AMBALAJ A.Ş. & General & B- & S & NP & No & \\
\hline ETI SODA A.Ş. & Metals \& mining & $A^{-}$ & S & $P$ & Yes & About the same \\
\hline IHLAS EV ALETLERI IMALAT SANAYI VE TICARET A.Ş. & General & C- & s & NP & No & \\
\hline PINAR ENTEGRE ET VE UN SANAYIi A.Ş. & Food, beverage \& tobacco & B & S & NP & Yes & Lower \\
\hline PINAR SÜT MAMULLERI SANAYIi A.Ş & Food, beverage \& tobacco & A- & s & NP & Yes & Higher \\
\hline SABANCI HOLDING A.Ş. & General & B & S & P & Yes & Lower \\
\hline ŞEKERBANK T.A.Ş. & Financial services & B & s & $P$ & Yes & \\
\hline T.GARANTI BANKASI A.Ş. & Financial services & B & s & P & Yes & About the same \\
\hline TÜRKIYE HALK BANKASI A.Ş. & Financial services & B & S & $P$ & Yes & About the same \\
\hline YAPI VE KREDI BANKASI A.Ş. & Financial services & $A^{-}$ & s & $P$ & Yes & Much higher \\
\hline YÜNSA YÜNLÜ SANAYI VE TICARET A.Ş. & General & B- & $\mathrm{s}$ & P & Yes & About the same \\
\hline ZORLU DOĞAL ELEKTRIK ÜRETIMI A.Ş. & Electric utilities & B & SA & NP & Yes & \\
\hline
\end{tabular}

\section{Key to Response Status Tables}

(S) Submitted (NS) Not submitted (No response or Declined to Participate) (SA) See Another (Company is either a subsidiary or the parent company is already responding to CDP) (P) Public (NP) Non-public (N/A) Not scored because company responded the short version of questionnaire (F) Failure to provide sufficient information to CDP to be evaluated for this purpose. 


\section{CDP PARTNER IN TURKEY \\ Sabancı University Corporate Governance Forum}

\section{Team Members}

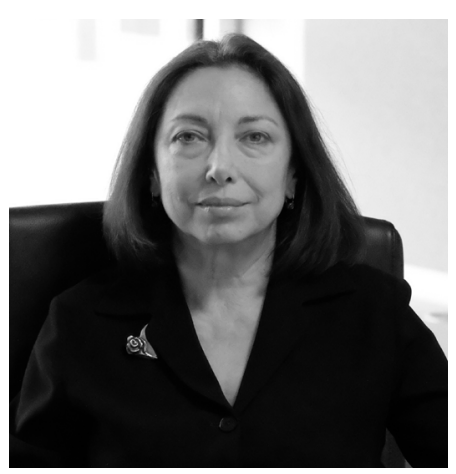

Melsa Ararat CDP Director

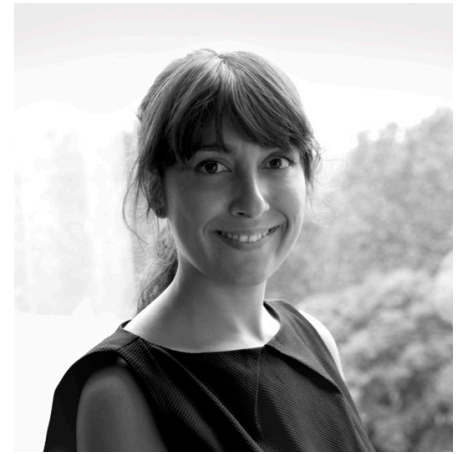

Mirhan Köroğlu Göğüş CDP Projects Manager

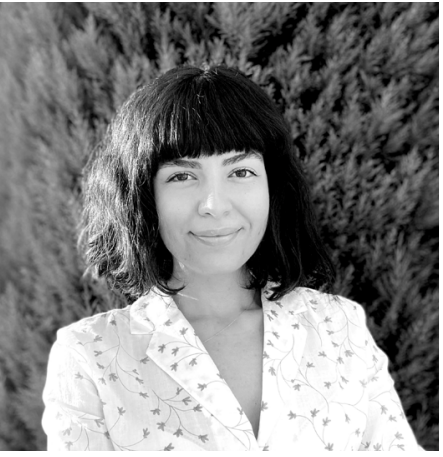

Firuze Alpaydın

CDP Project Officer

\section{Important Notice}

The contents of this report may be used by anyone providing acknowledgement is given to CDP Worldwide (CDP). This does not represent a license to repackage or resell any of the data reported to CDP or the contributing authors and presented in this report. If you intend to repackage or resell any of the contents of this report, you need to obtain express permission from CDP before doing so.

Sabancı University Corporate Governance Forum and CDP have prepared the data and analysis in this report based on responses to the CDP 2020 information request. No representation or warranty (express or implied) is given by Sabancı University Corporate Governance Forum or CDP as to the accuracy or completeness of the information and opinions contained in this report. You should not act upon the information contained in this publication without obtaining specific professional advice. To the extent permitted by law, Sabancı University Corporate Governance Forum and CDP do not accept or assume any liability, responsibility or duty of care for any consequences of you or anyone else acting, or refraining to act, in reliance on the information contained in this report or for any decision based on it. All information and views expressed herein by CDP and/or Sabancı University Corporate Governance Forum is based on their judgment at the time of this report and are subject to change without notice due to economic, political, industry and firm-specific factors. Guest commentaries where included in this report reflect the views of their respective authors; their inclusion is not an endorsement of them.

Sabancı University Corporate Governance Forum and CDP and their affiliated member firms or companies, or their respective shareholders, members, partners, principals, directors, officers and/or employees, may have a position in the securities of the companies discussed herein. The securities of the companies mentioned in this document may not be eligible for sale in some states or countries, nor suitable for all types of investors; their value and the income they produce may fluctuate and/or be adversely affected by exchange rates.

'CDP Worldwide' and 'CDP' refer to CDP Worldwide, a registered charity number 1122330 and a company limited by guarantee, registered in England number 05013650.

(c) 2020 CDP Worldwide. All rights reserved.

DOI number. 10.5900/SU_SOM_WP.2021.41326 


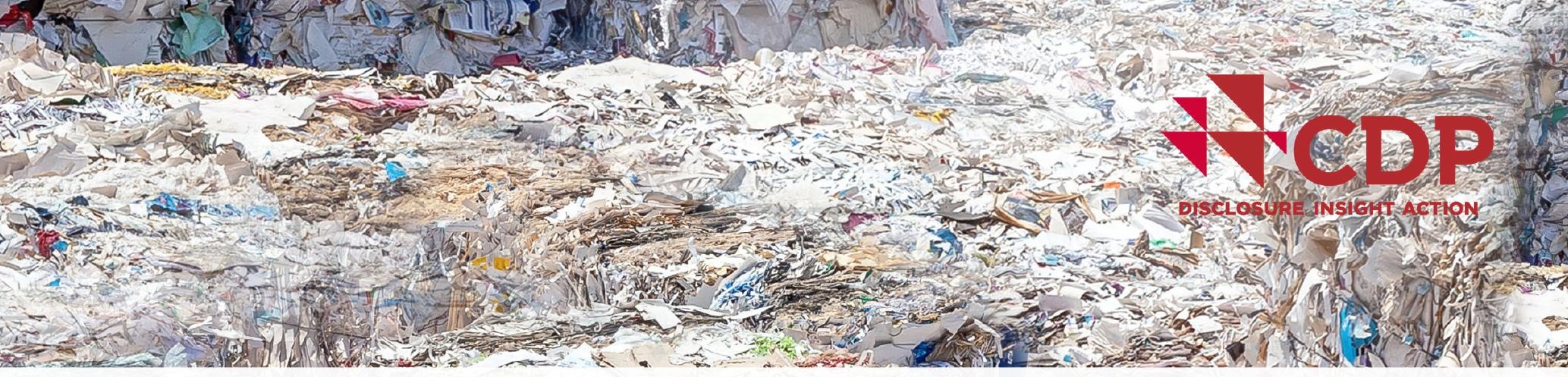

CDP Contacts

Sue Howells

Chief Operating Officer

Ji Yeon Kim

Manager, Partner Regions

\section{CDP Worldwide}

4th Floor Plantation Place South 60 Great Tower Street

London EC3R 5AD

Telephone: +44 (0) 2038183900 www.cdp.net
Partner Contacts

Melsa Ararat

Director

Mirhan Köroğlu Göğüş

Projects Manager

Sabancı University

Orhanlı/Tuzla 34956

Istanbul Turkey

Tel: +90 (0) 2164839682

cdpturkey.sabanciuniv.edu

mirhan.koroglu@sabanciuniv.edu
Report Writer Contacts

Mirhan Köroğlu Göğüş

CDP Turkey

Firuze Alpaydın

CDP Turkey
Report Design

Duygu Serin

Artimprojects

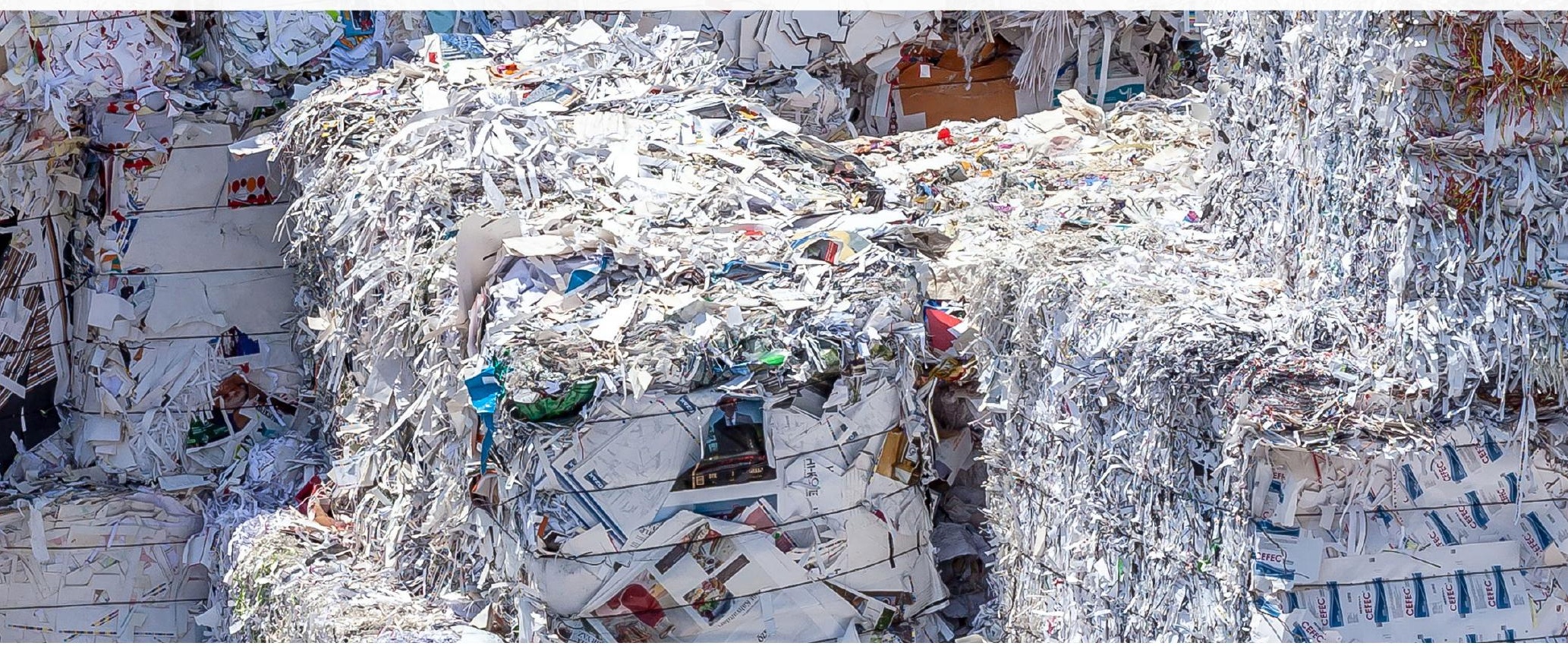

CDP Partner

Sabanci

Universitesı
CORPORATE

GOVERNANCE FORUM OF TURKEY
*Garanti BBVA

Deloitte. 